\title{
Biochemical and structural controls on the decomposition dynamics of boreal upland forest moss tissues
}

\author{
Michael Philben $^{1, \mathrm{a}}$, Sara Butler ${ }^{1, \mathrm{~b}}$, Sharon A. Billings ${ }^{2}$, Ronald Benner ${ }^{3,4}$, Kate A. Edwards ${ }^{5, \mathrm{c}}$, and Susan E. Ziegler ${ }^{1}$ \\ ${ }^{1}$ Department of Earth Sciences, Memorial University, St. John's, NL, Canada \\ ${ }^{2}$ Department of Ecology and Evolutionary Biology, Kansas Biological Survey, University of Kansas, Lawrence, KS, USA \\ ${ }^{3}$ Marine Science Program, University of South Carolina, Columbia, SC, USA \\ ${ }^{4}$ Department of Biological Sciences, University of South Carolina, Columbia, SC, USA \\ ${ }^{5}$ Natural Resources Canada, Canadian Forest Service, Atlantic Forestry Centre, NL, Canada \\ a present address: Environmental Science Division, Oak Ridge National Laboratory, Oak Ridge, TN, USA \\ b present address: Great Lakes Institute of Environmental Research, University of Windsor, Windsor, ON, Canada \\ ${ }^{\mathrm{c}}$ present address: Science Policy Integration Branch, Canadian Forest Service, \\ Natural Resources Canada, Ottawa, Ontario, Canada
}

Correspondence: Michael Philben (philbenmj@ornl.gov)

Received: 17 June 2018 - Discussion started: 21 June 2018

Revised: 11 October 2018 - Accepted: 20 October 2018 - Published: 13 November 2018

\begin{abstract}
Mosses contribute an average of $20 \%$ of boreal upland forest net primary productivity and are frequently observed to degrade slowly compared to vascular plants. If this is caused primarily by the chemical complexity of their tissues, moss decomposition could exhibit high temperature sensitivity (measured as $Q_{10}$ ) due to high activation energy, which would imply that soil organic carbon (SOC) stocks derived from moss remains are especially vulnerable to decomposition with warming. Alternatively, the physical structure of the moss cell-wall biochemical matrix could inhibit decomposition, resulting in low decay rates and low temperature sensitivity. We tested these hypotheses by incubating mosses collected from two boreal forests in Newfoundland, Canada, for 959 days at $5^{\circ} \mathrm{C}$ and $18^{\circ} \mathrm{C}$, while monitoring changes in the moss tissue composition using total hydrolyzable amino acid (THAA) analysis and ${ }^{13} \mathrm{C}$ nuclear magnetic resonance (NMR) spectroscopy. Less than $40 \%$ of $\mathrm{C}$ was respired in all incubations, revealing a large pool of apparently recalcitrant $\mathrm{C}$. The decay rate of the labile fraction increased in the warmer treatment, but the total amount of C loss increased only slightly, resulting in low $Q_{10}$ values (1.23-1.33) compared to $L$ horizon soils collected from the same forests. NMR spectra were dominated by $\mathrm{O}$-alkyl $\mathrm{C}$ throughout the experiment, indicating the persistence of potentially labile $\mathrm{C}$. The accumulation of hydroxyproline (de-
\end{abstract}

rived primarily from plant cell-wall proteins) and aromatic $\mathrm{C}$ indicates the selective preservation of biochemicals associated with the moss cell wall. This was supported by scanning electron microscope (SEM) images of the moss tissues, which revealed few changes in the physical structure of the cell wall after incubation. This suggests that the moss cellwall matrix protected labile $\mathrm{C}$ from microbial decomposition, accounting for the low temperature sensitivity of moss decomposition despite low decay rates. Climate drivers of moss biomass and productivity, therefore, represent a potentially important regulator of boreal forest SOC responses to climate change that needs to be assessed to improve our understanding of carbon-climate feedbacks.

\section{Introduction}

Boreal forests account for over half of global forest soil carbon (C) stocks, with areal soil C densities 2-3 times higher than temperate or tropical forests (Malhi et al., 1999). Many factors contribute to high $\mathrm{C}$ stocks, including low temperatures, high soil moisture in many regions, and the high relative abundance of plants with relatively slow-to-decay litter such as mosses (Coûteaux et al., 2002; Hobbie, 1996; Hobbie et al., 2000; Wetterstedt et al., 2010). However, the boreal 
region is warming more rapidly than the global mean (IPCC, 2013), which could lead to $C$ losses both from the direct effects of warming and drying (Kane et al., 2005) and from the indirect effects of changing $\mathrm{C}$ sources due to vegetation change (Gornall et al., 2007; Kohl et al., 2018; Turetsky et al., 2012).

Mosses contribute an average of about $20 \%$ of the total NPP in upland boreal forests (Turetsky et al., 2010) and can locally exceed vascular plant NPP (Frolking et al., 1996; Gower et al., 2001). Despite this, the unique dynamics of moss biogeochemistry are not typically included in models of boreal forest $\mathrm{C}$ cycling, which could result in considerable biases. For example, Bona et al. (2013) used a literature review of the rates of primary production and decomposition of upland mosses to estimate the range of moss $\mathrm{C}$ that could be stored in the soils of black spruce-dominated boreal forests, and the result (31\%-49\% of total soil organic carbon - SOC) was comparable to the difference between modeled and observed $\mathrm{C}$ stocks for those forests. This demonstrates that accurately representing moss production and decomposition is essential for modeling the $\mathrm{C}$ cycle in moss-rich boreal forests. While many studies estimate moss primary production, only three estimates of degradation rates were available for this meta-analysis, and none estimated the temperature sensitivity of moss decomposition (Bona et al., 2013). This is significant, because the limited numbers of studies of upland mosses show slower decomposition than vascular plant litter incubated under similar conditions (Harden et al., 1997; Moore and Basiliko, 2006). Omitting moss-specific dynamics could therefore overestimate decomposition and underestimate $\mathrm{C}$ storage in moss-rich soils.

Predicting the temperature sensitivity of moss decomposition is difficult, because it is not clear if the apparent recalcitrance of moss tissues is due to chemical complexity, physical and structural characteristics impeding microbial decomposition, or a combination of the two. Most studies of moss biochemistry have focused on the peat-forming Sphagnum genus, and it is not clear to what extent these insights apply to non-Sphagnum upland species. While mosses do not contain lignin (Maksimova et al., 2013), they do produce a variety of lignin-like phenols, which have been hypothesized to inhibit decomposition (Tsuneda et al., 2001). In addition, Sphagnum mosses produce structural carbohydrates that also appear to impede decomposition (Hájek et al., 2011; Turetsky et al., 2008). If the decomposition of upland mosses is limited by chemical properties, we might expect a higher temperature sensitivity of moss decomposition compared to vascular plant litter due to the higher activation energy of more chemically complex compounds (Bosatta and Ågren, 1999; Davidson and Janssens, 2006). This result would suggest that the moss $\mathrm{C}$ pool is not only under-represented in size due to slow decomposition, but it is also particularly vulnerable to decomposition with warming.

Distinct from moss chemical characteristics, the physiochemical matrix of moss cell walls also could play a role in limiting microbial access to moss tissues otherwise useful as microbial resources. Indeed, scanning electron micrographs of a slowly decomposing Sphagnum species (S. fuscum) revealed little change in the structure of the cell wall after 3 years of decomposition, suggesting that something inherent to moss cell-wall structure presented a barrier to microbial access, even long after cell death (Turetsky et al., 2008). If so, moss tissue chemistry per se may not require a higher activation energy than vascular plant tissues for decay to proceed, but decay instead would be limited by the poor physical accessibility of microbes to usable resources. However, it is not clear if the observed decay resistance is widespread, as the cell-wall structure of another Sphagnum species ( $S$. riparium) collapsed after 1 year of decomposition (Turetsky et al., 2008). The degree to which upland moss cell walls retain their physical structure after death and impede microbial decomposition remains unknown.

We observed the decay of upland boreal forest mosses collected from the Newfoundland and Labrador Boreal Ecosystem Latitudinal Transect (NL-BELT) for more than 2.5 years to investigate (1) the temperature sensitivity of moss tissue decomposition and (2) the relationship between moss chemical composition, cell-wall structure, and its decomposition. We combined chemical characterization with scanning electron microscopy (SEM) to determine both chemical and physical changes in the moss tissues during decomposition. In doing so we investigate the relative importance of these factors contributing to the slow turnover of moss tissues in these forests.

\section{Methods}

\subsection{Sample sites}

Moss samples were collected in July 2011 from two balsam-fir-dominated forest sites within the Newfoundland and Labrador Boreal Ecosystem Latitudinal Transect (NLBELT). One site was located in the Salmon River watershed near Main Brook on Newfoundland's northern peninsula (hereafter "northern forest"), and one was located in the Grand Codroy watershed in southwestern Newfoundland ("southern forest"). The mean annual temperature (MAT) in the northern forest is $3.2^{\circ} \mathrm{C}$ lower than in the southern forest $\left(2.0\right.$ vs. $5.2^{\circ} \mathrm{C}$; Table 1$)$, while mean annual precipitation is higher at the southern forest (1224 vs. $1505 \mathrm{~mm}$; Environment Canada Normals 1981-2010). Both sites contain humo-ferric podzol soils. Soil $\mathrm{pH}$ was measured on water extracts from $F$ and $H$ horizon soils and was low at both sites $(4.39 \pm 0.26$ at the northern forest and $4.03 \pm 0.22$ at the southern forest; Table 1). The dominant moss species were Dicranum spp. and Rhytidiadelphus triquetrus in the northern forest and Pleurozium schreberi, Hylocomium splendens, and Ptilium crista-castrensis in the southern forest, which had lower overall moss coverage based on the examination 
Table 1. Study site characteristics including mean annual temperature (MAT) and mean annual precipitation (MAP).

\begin{tabular}{|c|c|c|}
\hline & Salmon River & Grand Codroy \\
\hline & "Northern forest" & "Southern forest" \\
\hline Climate station & Main Brook & Doyles \\
\hline $\operatorname{MAT}\left({ }^{\circ} \mathrm{C}\right)^{\mathrm{a}}$ & $2.0 \pm 2.4$ & $5.2 \pm 2.0$ \\
\hline $\operatorname{MAP}(\mathrm{mm})^{\mathrm{a}}$ & 1223.9 & 1504.6 \\
\hline Rainfall $(\mathrm{mm})^{\mathrm{a}}$ & 708.8 & 1110.4 \\
\hline Snowfall $(\mathrm{cm})^{\mathrm{a}}$ & 515.0 & 394.2 \\
\hline $\mathrm{GSST}^{\mathrm{b}}$ & 14.00 & 16.0 \\
\hline Latitude & $51^{\circ} 15^{\prime} 21.28^{\prime \prime} \mathrm{N}$ & $47^{\circ} 53^{\prime} 36.34^{\prime \prime} \mathrm{N}$ \\
\hline Longitude & $56^{\circ} 8^{\prime} 17.76^{\prime \prime} \mathrm{W}$ & $59^{\circ} 10^{\prime} 28.31^{\prime \prime} \mathrm{W}$ \\
\hline Elevation (m) & 14 & 13.10 \\
\hline Soil $\mathrm{pH}$ & $4.39 \pm 0.26$ & $4.03 \pm 0.21$ \\
\hline Dominant moss species $^{\mathrm{c}}$ & Dicranum spp., Rhytidiadelphus triquetrus & $\begin{array}{l}\text { Pleurozium schreberi, Hylocomium splendens, } \\
\text { Ptilium crista-castrensis }\end{array}$ \\
\hline
\end{tabular}

a Canadian climate normals, 1981-2010, http://www.climate.weatheroffice.gc.ca/climate_normals/index_e.html (last access: 25 April 2018). MAT, mean annual temperature; MAP, mean annual precipitation. ${ }^{\mathrm{b}}$ Growing season soil temperature (GSST) averaged over July and August in 2010 based on data from the Canadian Forest Service - Atlantic Forestry Centre in Corner Brook, Newfoundland, Canada. ${ }^{c}$ Identified by Kate Buckeridge, Kyungjin Min, Kate Edwards, Andrea Skinner, Amanda Baker, and Danny Pink.

of $151 \mathrm{~m}^{2}$ plots at each site (Table 1). A total combined sample of over $50 \mathrm{~g}$ dry weight of moss tissue (green and brown parts) was sampled from across each site. To obtain a sample representative of each site, subsamples (10-20 g dry weight each) were collected over $\sim 3 \mathrm{~m}^{2}$ area in each of five locations around the entire edge and just outside of each site. This was done to avoid the destructive sampling of the moss layer within the study site. Moss samples were then separated into green and brown portions and rinsed with DI water. The green tissues of different species were mixed together to create a homogenized sample for each site. The collection was focused on accurately reflecting the moss cover at each site, and no effort was made to ensure all species were represented.

\subsection{Incubation experiment}

Incubations were designed to include four destructivesampling time points, which occurred at $69,283,648$, and 959 days from the beginning of the experiment, starting in October 2011. The green portion of moss tissues from both regions was incubated in the dark in sealed glass jars at 5 and $18^{\circ} \mathrm{C}$. For each site, 24 jars (three replicates per site, temperature, and time point combination) were established that contained $1,1.5,2.5$, or $2.75 \mathrm{~g}$ dry weight of moss tissue; jars containing greater weights were sampled at later time points. A microbial inoculum derived from each site's organic horizon was added to its respective jars at the start of the incubation experiment. The inoculum was created by saturating the soil sample from each site with Nano-UV water $\left(\sim 120\right.$ g dry weight soil $\left.\mathrm{L}^{-1}\right)$. The slurry was then filtered (GF/C; $1.2 \mu \mathrm{m}$ nominal pore size) to exclude most soil organic matter (SOM) while retaining many soil microorganisms and pipetted onto the moss sample in each jar at a volume required to achieve $60 \%$ water holding capacity (6-21 $\mathrm{mL}$ for the $1-2.75 \mathrm{~g}$ dry weight moss samples). Moss water holding capacity was predetermined on five replicate subsamples of each integrated moss sample. Whatman filter papers suspended on filter racks were saturated with water, and once these filters stopped dripping, five pre-weighed, $1 \mathrm{~g}$ (fresh weight) replicates of each site's moss sample was placed onto separate moistened filter papers, and water was slowly added until saturated and dripping. When the dripping stopped, moss tissue samples were scraped into pre-weighed oven tins and weighed. Following this each sample was ovendried in the same tin at $60^{\circ} \mathrm{C}$ for $>48 \mathrm{~h}$. Upon drying, each was weighed again and the amount of water per $g$ of the dry weight of the moss was calculated as the water holding capacity for that material $\left(\mathrm{mL} \mathrm{g}^{-1}\right)$.

Following inoculation, jars were sealed and incubated, with half the jars at $5^{\circ} \mathrm{C}$ and half at $18^{\circ} \mathrm{C}(12$ jars for each site and temperature combination). We opened all jars biweekly to allow for gas exchange and to add sufficient water to ensure moss was kept at approximately $60 \%$ water holding capacity. At each sampling time point all moss was removed from the jars and dried at $40^{\circ} \mathrm{C}$ to constant mass and weighed. Once weighed, moss was ground using a Wiley mill (Thomas Scientific, Swedesboro) with a 60 -mesh $(0.25 \mathrm{~mm})$ screen and stored in glass vials in the dark for subsequent analyses.

\subsection{Chemical analyses}

To determine how decomposition affected organic matter composition, the elemental and stable carbon and nitrogen isotopic composition of the moss samples were analyzed on a Carlo Erba NA 1500 Series elemental analyzer interfaced to a Delta V Plus isotope ratio mass spectrometer via a ConFloIII 
interface (ThermoFisher Scientific). In total 48 samples were analyzed, plus 6 initial samples were taken as random triplicates from the homogenized prepared moss tissue from each site.

Sub-samples of the initial and final (959 days) moss samples were analyzed using solid state cross-polarization magic-angle-spinning (CPMAS) ${ }^{13} \mathrm{C}$ nuclear magnetic resonance (NMR) to determine the proportions of carbon functional groups and how they changed with decomposition. Samples were analyzed using a Bruker Avance II $600 \mathrm{MHz}$ using a magic-angle-spinning probe for $\mathrm{H}, \mathrm{C}, \mathrm{N}$, and ${ }^{2} \mathrm{H}$ (MASHCCND). All samples were run at $150.96 \mathrm{MHz}$ for ${ }^{13} \mathrm{C}$ and spun at $20 \mathrm{kHz}$ at a constant temperature of $298 \mathrm{~K}$. Carbonyl and amide (190-165 ppm) were separated from each other by subtracting $\mathrm{N}: \mathrm{C}$ (multiplied by $100 \%$ ) from the total peak area ratio to determine the maximum amount carbonyl. The remaining provides an approximation of the maximum amide $\mathrm{C}$ proportion.

Water-soluble inorganic nitrogen, measured as nitrate plus nitrite and ammonium, was determined using a Lachat 8500 flow injection analyzer. All samples were first extracted using Nano-UV water. Briefly, $300 \mathrm{mg}$ of the ground moss material was shaken with $10 \mathrm{~mL}$ of water for 2 min at room temperature then centrifuged and filtered using a glass fiber filter ( $\mathrm{GF} / \mathrm{F}$; nominal pore size of $0.45 \mu \mathrm{m}$ ) to remove particulate matter. The filtrate was then analyzed for $\mathrm{NO}_{3}^{-}$and $\mathrm{NH}_{4}^{+}$ concentration to determine the total water soluble inorganic nitrogen content of each moss tissue sample.

Total hydrolyzable amino acids (THAAs) were analyzed following the method outlined in Philben et al. (2016), using the EZ:Faast kit for amino acid analysis (Phenomenex, USA). Briefly, a $20 \mathrm{mg}$ subsample of each moss sample was mixed with $1 \mathrm{~mL}$ of $6 \mathrm{M} \mathrm{HCl}$ acid in a $1 \mathrm{~mL}$ ampule, which was sealed, shaken, and heated at $110^{\circ} \mathrm{C}$ for $20 \mathrm{~h}$. Samples were then transferred to $2 \mathrm{~mL}$ vials and centrifuged. An aliquot of the resulting hydrosylate was transferred into a new vial and evaporated using $\mathrm{N}_{2}$ gas. $200 \mu \mathrm{L}$ of $0.01 \mathrm{M} \mathrm{HCl}$ was added to each hydrolysate along with norvaline, which was added as an internal standard. Amino acids were derivatized with propyl chloroformate using the EZ:Faast kit. Samples were analyzed on an Agilent 6890 gas chromatograph with a ZB-AAA column using a single-step oven program of $110-320^{\circ} \mathrm{C}$ at $30^{\circ} \mathrm{min}^{-1}$ and quantified using a flame ionization detector. Fifteen amino acids were determined; alanine, glycine, valine, leucine, isoleucine, threonine, serine, proline, aspartic acid, hydroxyproline (Hyp), glutamic acid, phenylalanine, lysine, histidine, and tyrosine.

\subsection{Scanning electron microscopy}

We performed scanning electron microscopy (SEM) on prepared fragments of the initial and final moss tissues from this experiment using a JEOL JSM 7100F Field Emission SEM equipment with a Thermo EDS. Three random subsamples were taken from the homogenized whole dried $\left(40^{\circ} \mathrm{C}\right)$ initial moss samples used to establish the incubation mesocosms. Subsamples of each of the final $18^{\circ} \mathrm{C}$ incubation samples were used to provide the most degraded samples to compare with the initial sample images. All samples were dried at $50^{\circ} \mathrm{C}$, mounted on aluminum stubs, and coated with 300 angstroms of gold using a SPI-Module Sputter Coater (Structure Probe, Inc.; West Chester, PA, USA).

\subsection{Data analysis}

The percent mass remaining was calculated using the dry weights of the initial and final mass at the four time points of the incubation. The mass remaining was then fit to the exponential decay equation to calculate the rate of decay:

$y=L\left(e^{-k t}\right)+R$,

where $L$ represents the labile fraction of mass that was decomposed by the end of the experiment, $R$ was the residual fraction was left undecomposed, $t$ represents time in days, and $k$ is the exponential decay constant $\left(\mathrm{day}^{-1}\right)$. The carbon and nitrogen remaining was also fit to Eq. (1) where possible.

$Q_{10}$ values were calculated to measure the temperature sensitivity of moss decomposition. This was performed by comparing $\mathrm{C}$ loss over the full experiment (Eq. 2) or using the $k$ values calculated in Eq. (1) to estimate the temperature sensitivity of decomposition of the labile fraction (Eq. 3):

$$
\begin{aligned}
& Q_{10, \text { Total }}=\left(\frac{\mathrm{CL}_{T_{2}}}{\mathrm{CL}_{T_{1}}}\right)^{\frac{10}{T_{2}-T_{1}}}, \\
& Q_{10, \text { Labile }}=\left(\frac{k_{T_{2}}}{k_{T_{1}}}\right)^{\frac{10}{T_{2}-T_{1}}},
\end{aligned}
$$

where $\mathrm{CL}$ indicates the percentage $\mathrm{C}$ loss, $T_{2}$ indicates the warmer temperature $\left(18^{\circ} \mathrm{C}\right)$, and $T_{1}$ indicates the cooler temperature $\left(5^{\circ} \mathrm{C}\right)$.

THAA data were analyzed to determine the percentages of total $\mathrm{C}$ or $\mathrm{N}$ as amino acids and their change over incubation time, using the equation from Philben et al. (2016):

$$
\begin{aligned}
\text { THAA }(\% \mathrm{C} \text { or } \mathrm{N}) & =\Sigma\left[\text { Yield }_{\mathrm{AA}} /(\mathrm{C} \text { or } \mathrm{N})\right] \\
& \times[\mathrm{wt} \%(\mathrm{C} \text { or } \mathrm{N})]_{\mathrm{AA}},
\end{aligned}
$$

where Yield $_{\mathrm{AA}} /(\mathrm{C}$ or $\mathrm{N})$ is the normalized yield of each amino acid (15 in total) in $\mathrm{mg}$ amino acid per $100 \mathrm{mg} \mathrm{C}$ or $\mathrm{N}$ and $[\mathrm{wt} \%(\mathrm{C} \text { or } \mathrm{N})]_{\mathrm{AA}}$ is the \% weight of $\mathrm{C}$ or $\mathrm{N}$ in the amino acid. This equation was used for each individual amino acid, which was then summed for each sample. The THAA results were also used to determine the degradation index, commonly used for interpreting the extent of organic matter diagenesis in aquatic environments (Dauwe et al., 1999; Dauwe and Middelburg, 1998; Menzel et al., 2015). The index was modified for use at the sites used in the current study to permit the assessment of the degradation state of the sites' soil organic matter pools (Philben et al., 2016). In that work, a 

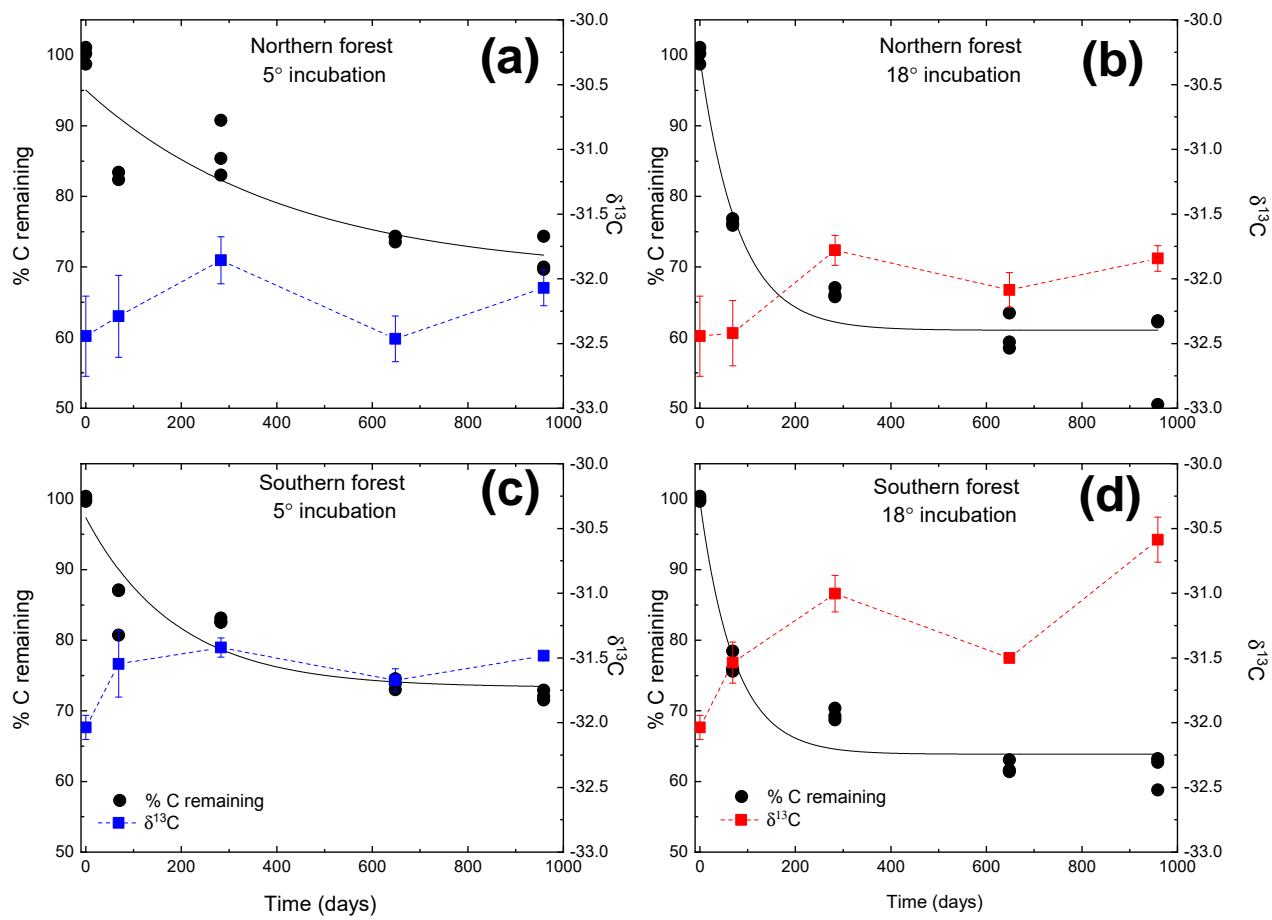

Figure 1. Moss tissue $\mathrm{C}$ remaining normalized to the initial tissue $\mathrm{C}$ (black circles). The solid black line represents the exponential fit used to assess the decay constant $(k)$. The $\delta^{13} \mathrm{C}$ values for the moss tissue at each time are indicated by squares and dashed lines, reported as the mean $(n=3)$ with the standard error depicted by error bars. Panels (a) and (c) depict (blue lines and symbols) results of the $5^{\circ} \mathrm{C}$ incubation, and panels (b) and (d) depict (red lines and symbols) the $18{ }^{\circ} \mathrm{C}$ incubation.

principle component analysis (PCA) of a data set, including the green portion of moss tissues, pooled needle litterfall, and $L, F, H$, and $B$ soil horizons from three regions within the NL-BELT, was conducted to identify the most significant differences in the overall THAA composition. Scores of the first principle component declined with increasing decomposition. This approach allows for the comparison of the moss tissues in the current incubation study and the soil profiles at each site. The equation taken from Philben et al. (2016) was represented as the following:

Degradation Index $=\left[\sum_{i}\left(\frac{\mathrm{Mol}_{i}-\mathrm{Avg}_{i}}{\mathrm{SD}_{i}}\right) \times \mathrm{PCl}_{i}\right]$,

where $\operatorname{Avg}_{i}$ and $\mathrm{SD}_{i}$ are the average and standard deviation of the individual amino acid ( $\mathrm{mol} \%)$ determined for the data set described above, $\mathrm{Mol}_{i}$ is the mol\% of each amino acid analyzed from the mosses, and $\mathrm{PCl}_{i}$ is the loading of the amino acids on the first principle component of the PCA performed on the data set of all litter, soil horizons, and moss from all regions across the NL-BELT. See Philben et al. (2016) for more details.

To test for the effects of incubation temperature, site, and their interaction on all quantified variables, we applied a twoway ANOVA using a mixed effects model. Additional twoway ANOVA tests were conducted for each time point to determine if any observed treatment effects changed over the course of the incubation. A two-way ANOVA was conducted to test the effects of site and temperature on alkyl : O-alkyl, using the initial moss samples, final (day 959) moss samples at $5^{\circ} \mathrm{C}$ and $18{ }^{\circ} \mathrm{C}$, and the effects of site and time (before or after incubation) on mol\% Hyp, $\mathrm{N}$ speciation, and the degradation index. All analyses were conducted in R 3.3.2 (R Core Team, 2016).

\section{Results}

\subsection{Moss tissue decay rates and mass and elemental loss}

Both $\mathrm{C}$ and mass loss measured in this experiment were fit to an exponential equation as described in the methods (Fig. 1). When incubated at $18{ }^{\circ} \mathrm{C}$, between $34 \%$ and $38 \%$ of the initial moss was lost, based on both the mass and $\mathrm{C}$ loss results. The rate of loss in the $18^{\circ} \mathrm{C}$ incubation declined over time, with rapid loss from 0-283 days, fewer changes from 283648 days, and no changes from 648 to 959 days. In the $5^{\circ} \mathrm{C}$ incubations, between $28 \%$ and $30 \%$ of mass or C was lost, with mass and $\mathrm{C}$ losses continuing throughout the incubation. Regardless of incubation temperature, the percentage of mass or $\mathrm{C}$ remaining at the end of the 959 days was not different between sites (Table 2). Decay constants ( $k$ ) associated with moss tissue mass or $\mathrm{C}$ remaining did not differ be- 
Table 2. Results from two-way ANOVA tests of the effects of collection site and incubation temperature on mass, $\mathrm{C}$ and $\mathrm{N}$ remaining, molar $\mathrm{C}$ to $\mathrm{N}$ ratio $(\mathrm{C}: \mathrm{N})$, and stable $\mathrm{C}\left(\delta^{13} \mathrm{C}\right)$ and $\mathrm{N}\left(\delta^{15} \mathrm{~N}\right)$ isotope of the moss tissues. Results provided for both the full experiment (using a repeated measures ANOVA) and for each incubation time (using 2-way ANOVA). Bolded values are significant $(\alpha=0.05)$.

\begin{tabular}{|c|c|c|c|c|c|c|c|c|c|c|}
\hline & & \multicolumn{3}{|c|}{ Temperature } & \multicolumn{3}{|c|}{ Region } & \multicolumn{3}{|c|}{ Interaction } \\
\hline & & df & $F$ & $p$ value & $n$ & $F$ & $p$ value & $n$ & $F$ & $p$ value \\
\hline \multirow{6}{*}{$\begin{array}{l}\text { \% mass remaining } \\
\text { (log transformed) }\end{array}$} & Full experiment & 54 & 8.7106 & 0.005 & 54 & 0.034 & 0.855 & 54 & 0.9643 & 0.331 \\
\hline & 0 & $\mathrm{n} / \mathrm{a}$ & $\mathrm{n} / \mathrm{a}$ & $\mathrm{n} / \mathrm{a}$ & $\mathrm{n} / \mathrm{a}$ & $\mathrm{n} / \mathrm{a}$ & $\mathrm{n} / \mathrm{a}$ & $\mathrm{n} / \mathrm{a}$ & $\mathrm{n} / \mathrm{a}$ & $\mathrm{n} / \mathrm{a}$ \\
\hline & 69 & 1 & 58.034 & $<0.001$ & 1 & 7.158 & 0.028 & 1 & 0.595 & 0.463 \\
\hline & 283 & 1 & 177.465 & $<0.001$ & 1 & 1.327 & 0.283 & 1 & 11.79 & 0.009 \\
\hline & 648 & 1 & 192.503 & $<0.001$ & 1 & 10.984 & 0.011 & 1 & 3.782 & 0.088 \\
\hline & 959 & 1 & 13.216 & 0.007 & 1 & 2.036 & 0.191 & 1 & 0.559 & 0.476 \\
\hline \multirow{6}{*}{$\begin{array}{l}\% \mathrm{C} \text { remaining } \\
\text { (log transformed) }\end{array}$} & Full experiment & 54 & 12.547 & $<0.001$ & 54 & 0.004 & 0.948 & 54 & 0.3615 & 0.550 \\
\hline & 0 & $\mathrm{n} / \mathrm{a}$ & $\mathrm{n} / \mathrm{a}$ & $\mathrm{n} / \mathrm{a}$ & 54 & $\mathrm{n} / \mathrm{a}$ & $\mathrm{n} / \mathrm{a}$ & $\mathrm{n} / \mathrm{a}$ & $\mathrm{n} / \mathrm{a}$ & $\mathrm{n} / \mathrm{a}$ \\
\hline & 69 & 1 & 43.420 & $<0.001$ & $\mathrm{n} / \mathrm{a}$ & 0.881 & 0.375 & 1 & 0.365 & 0.562 \\
\hline & 283 & 1 & 245.256 & $<0.001$ & 1 & 0.025 & 0.879 & 1 & 9.914 & 0.014 \\
\hline & 648 & 1 & 189.016 & $<0.001$ & 1 & 0.694 & 0.429 & 1 & 1.175 & 0.310 \\
\hline & 959 & 1 & 22.573 & 0.001 & 1 & 0.834 & 0.388 & 1 & 0.355 & 0.568 \\
\hline \multirow{6}{*}{$\begin{array}{l}\% \mathrm{~N} \text { remaining } \\
\text { (log transformed) }\end{array}$} & Full experiment & 54 & 3.749 & 0.058 & 1 & 3.496 & 0.067 & 54 & 1.4262 & 0.238 \\
\hline & 0 & $\mathrm{n} / \mathrm{a}$ & $\mathrm{n} / \mathrm{a}$ & $\mathrm{n} / \mathrm{a}$ & $\mathrm{n} / \mathrm{a}$ & $\mathrm{n} / \mathrm{a}$ & $\mathrm{n} / \mathrm{a}$ & $\mathrm{n} / \mathrm{a}$ & $\mathrm{n} / \mathrm{a}$ & $\mathrm{n} / \mathrm{a}$ \\
\hline & 69 & 1 & 5.131 & 0.053 & 1 & 1.629 & 0.238 & 1 & 0.484 & 0.506 \\
\hline & 283 & 1 & 2.436 & 0.157 & 1 & 6.859 & 0.031 & 1 & 0.129 & 0.729 \\
\hline & 648 & 1 & 15.150 & 0.005 & 1 & 61.010 & $<0.001$ & 1 & 11.32 & 0.010 \\
\hline & 959 & 1 & 0.142 & 0.716 & 1 & 10.603 & 0.012 & 1 & 1.884 & 0.207 \\
\hline \multirow{6}{*}{$\begin{array}{l}\mathrm{C}: \mathrm{N} \\
(\log \text { transformed) }\end{array}$} & Full experiment & 54 & 0.018 & 0.893 & 54 & 69.954 & $<0.001$ & 54 & 4.984 & $\mathbf{0 . 0 3 0}$ \\
\hline & 0 & 1 & $\mathrm{n} / \mathrm{a}$ & $\mathrm{n} / \mathrm{a}$ & 1 & 248.500 & $<0.001$ & 1 & $\mathrm{n} / \mathrm{a}$ & $\mathrm{n} / \mathrm{a}$ \\
\hline & 69 & 1 & 0.850 & 0.383 & 1 & 164.055 & $<0.001$ & 1 & 0.143 & 0.715 \\
\hline & 283 & 1 & 5.245 & 0.051 & 1 & 51.785 & $<0.001$ & 1 & 7.452 & 0.026 \\
\hline & 648 & 1 & 1.669 & 0.232 & 1 & 12.045 & 0.008 & 1 & 9.447 & 0.015 \\
\hline & 959 & 1 & 12.035 & 0.009 & 1 & 14.156 & 0.006 & 1 & 2.948 & 0.124 \\
\hline \multirow[t]{6}{*}{$\delta^{13} \mathrm{C}$} & Full experiment & 54 & 4.342 & 0.042 & 54 & 6.342 & 0.015 & 54 & 0.869 & 0.356 \\
\hline & 0 & 1 & $\mathrm{n} / \mathrm{a}$ & $\mathrm{n} / \mathrm{a}$ & 1 & 3.175 & 0.113 & 1 & $\mathrm{n} / \mathrm{a}$ & $\mathrm{n} / \mathrm{a}$ \\
\hline & 69 & 1 & 0.057 & 0.818 & 1 & 10.418 & 0.012 & 1 & 0.077 & 0.788 \\
\hline & 283 & 1 & 3.389 & 0.103 & 1 & 20.498 & 0.002 & 1 & 1.610 & 0.240 \\
\hline & 648 & 1 & 5.213 & 0.052 & 1 & 32.657 & $<0.001$ & 1 & 0.712 & 0.423 \\
\hline & 959 & 1 & 21.328 & 0.002 & 1 & 57.429 & $<0.001$ & 1 & 7.587 & 0.025 \\
\hline \multirow[t]{6}{*}{$\delta^{15} \mathrm{~N}$} & Full experiment & 54 & 3.197 & 0.081 & 54 & 0.834 & 0.365 & 54 & 1.174 & 0.245 \\
\hline & 0 & 1 & $\mathrm{n} / \mathrm{a}$ & $\mathrm{n} / \mathrm{a}$ & 1 & 7.148 & 0.028 & 1 & $\mathrm{n} / \mathrm{a}$ & $\mathrm{n} / \mathrm{a}$ \\
\hline & 69 & 1 & 0.098 & 0.762 & 1 & 1.730 & 0.225 & 1 & 0.071 & 0.797 \\
\hline & 283 & 1 & 120.174 & $<0.001$ & 1 & 2.349 & 0.164 & 1 & 1.179 & 0.309 \\
\hline & 648 & 1 & 0.117 & 0.742 & 1 & 6.704 & 0.032 & 1 & 0.117 & 0.742 \\
\hline & 959 & 1 & 0.043 & 0.841 & 1 & 0.537 & 0.485 & 1 & 1.306 & 0.286 \\
\hline
\end{tabular}

$\mathrm{n} / \mathrm{a}-$ not applicable.

tween sites and were greater in the $18^{\circ} \mathrm{C}$ incubation than at $5^{\circ} \mathrm{C}(-0.0130 \pm 0.0015$ vs. $-0.00380 \pm 0.0007$, respectively; average \pm standard deviation). The $Q_{10}$ values of mass loss during the full incubation $\left(Q_{10, \text { total }}\right)$ averaged 1.24 and did not vary by site. The $Q_{10}$ values of the labile pool calculated from the fitted $k$ values were 3.56 and 2.08 for the northern and southern forests, respectively.
The $\mathrm{N}$ remaining did not follow the same trend as mass and $\mathrm{C}$ and could not be fitted to an exponential curve but rather exhibited both increases and decreases over the course of the incubation (Fig. 2). One treatment (the southern forest at $18^{\circ} \mathrm{C}$ ) experienced a net gain in total $\mathrm{N}$ during the incubation, suggesting that $\mathrm{N}$ fixation occurred. Temperature did not have an effect on $\mathrm{N}$ remaining at most time points (Table 2). However, the collection site had an effect on $\mathrm{N}$ remaining during decomposition at all time points except on 

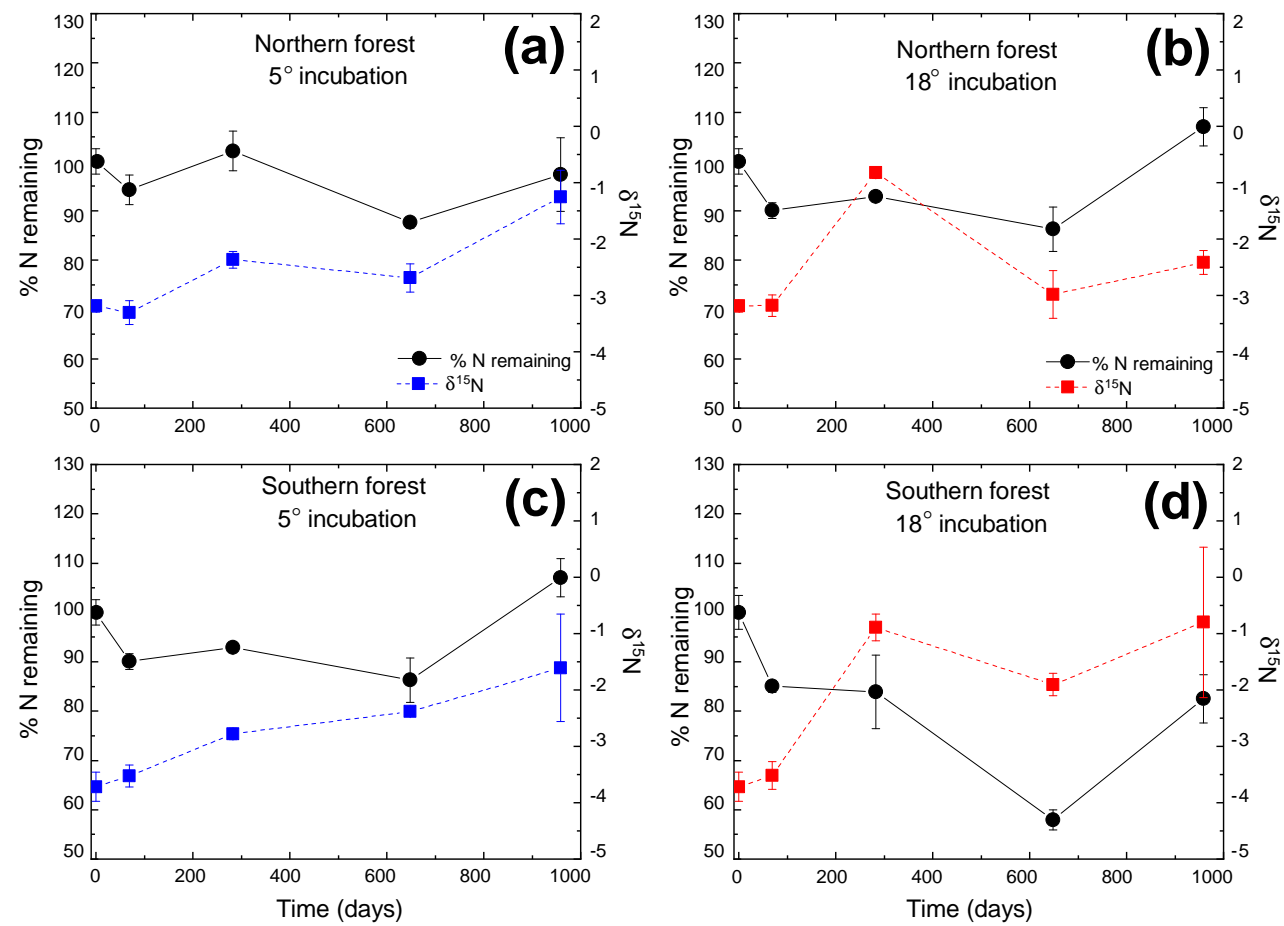

Figure 2. Percentage of initial nitrogen remaining (circles and solid lines) and $\delta^{15} \mathrm{~N}$ (squares and dashed lines) at each time point. Points indicate the mean $(n=3)$, with standard error depicted by error bars. Values in blue (a and $\mathbf{c})$ are results from the $5^{\circ} \mathrm{C}$ incubation, and those in red (b and $\mathbf{d})$ are from the $18^{\circ} \mathrm{C}$ incubation.

day 69 due to greater $\mathrm{N}$ loss during the $18^{\circ} \mathrm{C}$ incubation of moss from the southern forest (up to $46 \%$; Table 2).

\subsection{Elemental and stable isotope composition of decaying moss tissues}

Mosses collected from the two sites differed in initial $\mathrm{N}$ concentration $(0.92 \pm 0.05 \%$ and $0.59 \pm 0.03 \%$ in the southern and northern forest site, respectively; $p<0.001$ ) but were not different in C concentration $(43.9 \pm 0.1 \%$ and $43.6 \pm$ $0.5 \%$, respectively; Table 3 ). This variation in $\mathrm{N}$ was responsible for the lower $\mathrm{C}: \mathrm{N}$ ratio of $55.6 \pm 3$ at the southern forest relative to the higher value of $86.3 \pm 3$ at the northern forest $(p<0.001)$. However, $\mathrm{C}: \mathrm{N}$ declined with decomposition to a greater extent in the northern forest than in the southern forest, and the site difference in $\mathrm{C}: \mathrm{N}$ decreased with incubation time (Fig. 3). Though the effect of site on $\mathrm{C}: \mathrm{N}$ of the moss tissue was significant throughout the experiment, the differences between sites became less pronounced with time, especially in the $18^{\circ} \mathrm{C}$ incubations, and the $p$ value increased over the course of the experiment (Table 3 ).

The initial $\delta^{13} \mathrm{C}$ and $\delta^{15} \mathrm{~N}$ values of moss did not differ between sites. $\delta^{13} \mathrm{C}$ was $-31.8 \pm 0.5 \%$ and $-32.0 \pm$ $0.2 \%$ for the northern and southern forests, while $\delta^{15} \mathrm{~N}$ was $-3.19 \pm 0.2 \%$ and $-3.72 \pm 0.4 \%$, respectively. Moss $\delta^{13} \mathrm{C}$ increased over the course of the $18^{\circ} \mathrm{C}$ incubation for both sites $(p=0.010)$ and only increased during the $5{ }^{\circ} \mathrm{C}$ incu- bation for the southern forest. The increase in $\delta^{13} \mathrm{C}$ was greatest in the $18^{\circ} \mathrm{C}$ incubation of southern forest mosses (1.5\%; Fig. 1). In all other incubations, $\delta^{13} \mathrm{C}$ increased by less than $1 \%$, with most of that change occurring within the first 400 days, when the rate of $\mathrm{C}$ and mass loss was highest. Therefore, although the $\delta^{13} \mathrm{C}$ of moss tissues was not different for the initial values collected, the $\delta^{13} \mathrm{C}$ values differed by site throughout the decomposition experiment, with the significance of that difference increasing with decomposition (Table 2). There was no effect of temperature on the $\delta^{13} \mathrm{C}$ until the final time point, when site, temperature, and their interaction had a significant effect due to an increase of $\delta^{13} \mathrm{C}$ values in the southern forest's $18^{\circ} \mathrm{C}$ incubation to $-30.6 \pm 0.3 \%$ o. Temperature, but not site, had an effect on $\delta^{15} \mathrm{~N}(p=0.035$; Table 2$) . \delta^{15} \mathrm{~N}$ increased during incubation, in all treatments except for the northern forest at $18^{\circ} \mathrm{C}$, by an average of $2.3 \pm 1.5 \%$ o (Fig. 2).

\subsection{Molecular composition of $\mathrm{C}$ and $\mathrm{N}$, and SEM images of decaying moss tissues}

Nitrogen was further characterized into four compound classes, namely nitrate + nitrite, ammonium, total hydrolyzable amino acids, and molecularly unidentified N (MUN), and was expressed as a fraction of total $\mathrm{N}$ content (Fig. 4). Water-extractable ammonium increased slightly, with decomposition from initial values of $2 \%-2.5 \%$ to $4 \%-7 \%$ in 
Table 3. The CPMAS ${ }^{13} \mathrm{C}-\mathrm{NMR}$ results given as percentages of total $\mathrm{C}$ resolved for each chemical shift range, molar $\mathrm{C}$-to- $\mathrm{N}$ ratio (C : $\mathrm{N}$ ), and weight $\% \mathrm{C}$ and $\mathrm{N}$ of the initial and final moss tissues from both sites and incubated at $5{ }^{\circ} \mathrm{C}$ and $18^{\circ} \mathrm{C}$ top. All values are provided as the mean \pm on standard deviation of three replicates.

\begin{tabular}{|c|c|c|c|c|c|c|}
\hline & \multicolumn{3}{|c|}{ Northern forest } & \multicolumn{3}{|c|}{ Southern forest } \\
\hline & Initial & Final $\left(5^{\circ} \mathrm{C}\right)$ & Final $\left(18^{\circ} \mathrm{C}\right)$ & Initial & Final $\left(5^{\circ} \mathrm{C}\right)$ & Final $\left(18^{\circ} \mathrm{C}\right)$ \\
\hline Alkyl (50-0) & $9.08 \pm 0.2$ & $8.23 \pm 0.6$ & $8.57 \pm 2$ & $9.88 \pm 0.5$ & $8.66 \pm 0.2$ & $7.57 \pm 0.7$ \\
\hline O-alkyl (90-65) & $55.31 \pm 0.3$ & $54.01 \pm 1.0$ & $55.36 \pm 3$ & $54.75 \pm 1.6$ & $54.98 \pm 0.5$ & $57.09 \pm 0.3$ \\
\hline Di-O-alkyl (110-90) & $15.57 \pm 0.1$ & $15.32 \pm 0.1$ & $15.19 \pm 1$ & $15.11 \pm 0.1$ & $15.06 \pm 0.2$ & $15.49 \pm 0.1$ \\
\hline Aromatic $(145-110)$ & $4.44 \pm 0.2$ & $7.18 \pm 0.1$ & $6.55 \pm 0.02$ & $5.05 \pm 1.9$ & $6.05 \pm 0.004$ & $5.64 \pm 0.9$ \\
\hline Phenolic (165-145) & $2.35 \pm 0.2$ & $2.07 \pm 0.1$ & $1.74 \pm 0.2$ & $1.68 \pm 0.4$ & $1.57 \pm 0.1$ & $1.24 \pm 0.01$ \\
\hline Carbonyl and amide (190-165) & $3.40 \pm 0.2$ & $4.76 \pm 0.2$ & $4.61 \pm 1$ & $4.15 \pm 0.1$ & $5.12 \pm 0.2$ & $4.69 \pm 0.2$ \\
\hline Aromatic and phenolic $(145-110)$ & $6.79 \pm 0.4$ & $9.25 \pm 0.1$ & $8.29 \pm 0.2$ & $6.74 \pm 2.3$ & $7.62 \pm 0.1$ & $6.87 \pm 0.9$ \\
\hline O-alkyl : Di-O-alkyl & $3.55 \pm 0.03$ & $3.53 \pm 0.04$ & $3.64 \pm 0.1$ & $3.62 \pm 0.1$ & $3.65 \pm 0.01$ & $3.69 \pm 0.002$ \\
\hline Alkyl : O-alkyl & $0.16 \pm 0.003$ & $0.15 \pm 0.01$ & $0.16 \pm 0.04$ & $0.18 \pm 0.004$ & $0.16 \pm 0.002$ & $0.13 \pm 0.01$ \\
\hline Carboxyl/ester * & $2.24 \pm 0.1$ & $3.14 \pm 0.2$ & $2.43 \pm 1$ & $2.30 \pm 0.1$ & $2.92 \pm 0.5$ & $2.39 \pm 0.1$ \\
\hline Amide* & $1.16 \pm 0.06$ & $1.62 \pm 0.4$ & $2.18 \pm 0.1$ & $1.85 \pm 0.1$ & $2.20 \pm 0.2$ & $2.30 \pm 0.04$ \\
\hline$\% \mathrm{C}$ & $43.6 \pm 0.5$ & $44.4 \pm 0.4$ & $43.3 \pm 0.3$ & $43.9 \pm 0.1$ & $44.1 \pm 0.2$ & $42.3 \pm 0.7$ \\
\hline$\% \mathrm{~N}$ Nitrogen & $0.590 \pm 0.03$ & $0.823 \pm 0.1$ & $1.08 \pm 0.07$ & $0.920 \pm 0.05$ & $1.12 \pm 0.09$ & $1.19 \pm 0.08$ \\
\hline $\mathrm{C}: \mathrm{N}$ & $86.3 \pm 3$ & $64.0 \pm 9.7$ & $46.9 \pm 2.7$ & $55.6 \pm 3.2$ & $46.1 \pm 3.7$ & $41.6 \pm 3.4$ \\
\hline$\delta^{15} \mathrm{~N}$ & $-3.19 \pm 0.2$ & $-1.25 \pm 0.8$ & $-2.42 \pm 0.4$ & $-3.72 \pm 0.4$ & $-1.61 \pm 2$ & $-0.8 \pm 2$ \\
\hline$\delta^{13} \mathrm{C}$ & $-31.8 \pm 0.5$ & $-32.1 \pm 0.2$ & $-31.8 \pm 0.2$ & $-32.0 \pm 0.2$ & $-31.5 \pm 0.03$ & $-30.6 \pm 0.3$ \\
\hline$\% \mathrm{~N}$ as nitrate + nitrite & $0.058 \pm 0.006$ & $6.5 \pm 9.0$ & $10.4 \pm 9$ & $0.034 \pm 0.003$ & $7.27 \pm 11$ & $6.21 \pm 10.0$ \\
\hline$\% \mathrm{~N}$ as ammonium & $2.41 \pm 0.1$ & $8.41 \pm 2.0$ & $5.24 \pm 2$ & $1.59 \pm 0.06$ & $8.14 \pm 3$ & $6.99 \pm 1.0$ \\
\hline$\% \mathrm{C}$ as amino acids & $2.54 \pm 0.03$ & n.d. & $2.31 \pm 0.7$ & $3.83 \pm 0.03$ & n.d. & $2.12 \pm 0.7$ \\
\hline$\% \mathrm{~N}$ as amino acids & $52.1 \pm 1.1$ & n.d. & $26.4 \pm 6.6$ & $50.9 \pm 5$ & n.d. & $21.2 \pm 3.0$ \\
\hline Total amino acids (nmol mg ${ }^{-1}$ ) & $207.2 \pm 3$ & n.d. & $193.0 \pm 60$ & $313.0 \pm 30$ & n.d. & $171.0 \pm 20.0$ \\
\hline
\end{tabular}

* Maximum estimated value for amide-C and carboxyl/ester-C determined from the carbonyl-C and $\mathrm{C}: \mathrm{N}$ ratio; see methods for details. n.d. - not determined.

the $18{ }^{\circ} \mathrm{C}$ treatment $(p<0.001)$ and $5 \%-11 \%$ in the $5{ }^{\circ} \mathrm{C}$ treatment $(p<0.001)$. Extractable nitrate + nitrite was less than $1 \%$ of total $\mathrm{N}$ in most samples, with the exception of the final time point, when some nitrate + nitrite values reached up to $20 \%$ of total N. Relatively high nitrate concentrations at the final time point were associated with elevated $\mathrm{N}$ remaining values (>100\%) and more negative $\delta^{15} \mathrm{~N}$ values (Figs. 2 and 4). THAAs declined from $51.2 \pm 3 \%$ and $50.9 \pm 5 \%$ to $26.4 \pm 7 \%$ and $21.2 \pm 3 \%$ of the total $\mathrm{N}$ in the northern and southern forests, respectively $(p<0.001)$, and the effect of the site was not significant on the decline. The decline in the $\% \mathrm{~N}$ as THAAs over the incubation coincided with changing amino acid composition, as the degradation index also declined, as expected with decomposition $(p<0.001)$. The change was larger in the northern forest, declining from $1.4 \pm 0.7$ and $2.6 \pm 0.5$ to $-1.6 \pm 0.5$ and $-1.3 \pm 0.1$ in the southern and northern forest, respectively $(p=0.0388)$. Mole\% Hyp increased over the first 69 days in both sites (from $0.9 \%$ to $1.5 \%$ in the southern forest and $1.1 \%$ to $1.3 \%$ in the northern forest; Fig. 5). It remained elevated for the remainder of the incubation in the southern forest and was significantly higher than the initial value ( $p=0.0496)$, but it declined back to $1.1 \%$ in the northern forest after 959 days. Because $\% \mathrm{~N}$ as THAAs declined with little change in the inorganic $\mathrm{N}$ pools, MUN increased in relative abundance with decomposition in both regions.

The CPMAS ${ }^{13}$ C-NMR results indicate that the moss tissues from both forest sites were similar and dominated by O-alkyl and di-O-alkyl C (70\%) with relatively little alkyl, carbonyl, or aromatic C (Fig. 6; Table 3). The NMR spectra of the moss tissues before and after incubation were broadly similar and exhibited little change in the relative proportions of the major $\mathrm{C}$ groups. As a result, the alkyl : O-alkyl ratio also exhibited no change with decomposition, regardless of collection site and despite up to $50 \%$ mass loss. The largest change observed was in the calculated maximum amide value from the carbonyl- $\mathrm{C}$ and amide- $\mathrm{C}$ resolved at chemical shift $190-165 \mathrm{ppm}$. Calculated maximum amide-C increased from $1.85 \pm 0.1 \%$ to $2.30 \pm 0.04 \%$ and $1.16 \pm 0.06 \%$ to $2.18 \pm 0.1 \%$ for mosses incubated at $18{ }^{\circ} \mathrm{C}$ from northern and southern forests, respectively. Amino acids are likely a major source of amide $\mathrm{C}$; however, the $\% \mathrm{C}$ as THAAs declined with decomposition, indicating that the increasing relative abundance of amide $\mathrm{C}$ was due to MUN compounds.

SEM imaging revealed few apparent differences between the physical structure of moss tissues before and after incubation (Figs. 7, S1, and S2). Intact moss cell walls were visible in both sets of images, with few signs of structural change. There was no evidence of warping, gouging, or pitting from 

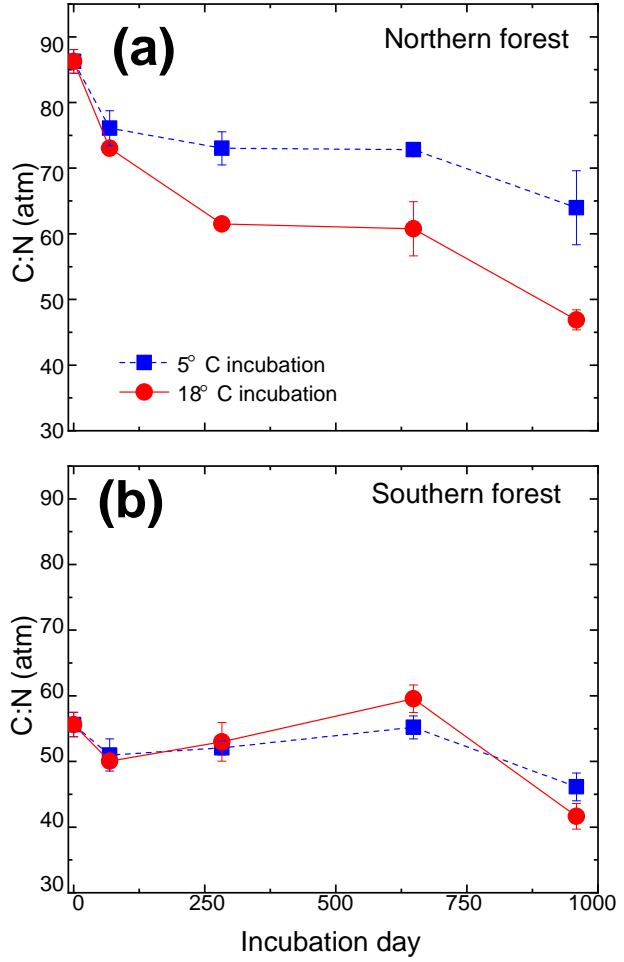

Figure 3. Molar carbon-to-nitrogen ratio of moss tissues from the cooler (a) and warmer (b) forest sites plotted against incubation time. Values for the $5^{\circ} \mathrm{C}$ and $18^{\circ} \mathrm{C}$ incubations temperatures are given by the blue squares and red circles, respectively, and are reported as the mean $(n=3)$, with standard error depicted by error bars.

the microbial degradation of the cell wall following the incubation of mosses from either region.

\section{Discussion}

\subsection{Decomposition of mosses is slower and less temperature sensitive than vascular plants}

The low decay rates observed are consistent with previous studies of moss decomposition (Fyles and McGill, 1987; Hobbie et al., 2000; Hogg, 1993; Hagemann and Moroni, 2015). Decay rates of moss tissues are typically lower than rates for vascular plant decay under similar conditions (Fyles and McGill, 1987; Hagemann and Moroni, 2015; Hobbie, 1996). Mass loss during the 1-year litter bag decomposition of balsam fir needles averaged $27 \%$ at the northern forest and $35 \%$ at the southern forest (Kate A. Edwards, unpublished data). The needles therefore experienced a similar mass loss in 1 year to the mosses after 959 days, indicating more rapid decomposition. The moss decay rates can also be compared to the incubations of $L$ horizon soils collected from these sites, which were comprised of $\sim 66 \%$ par-

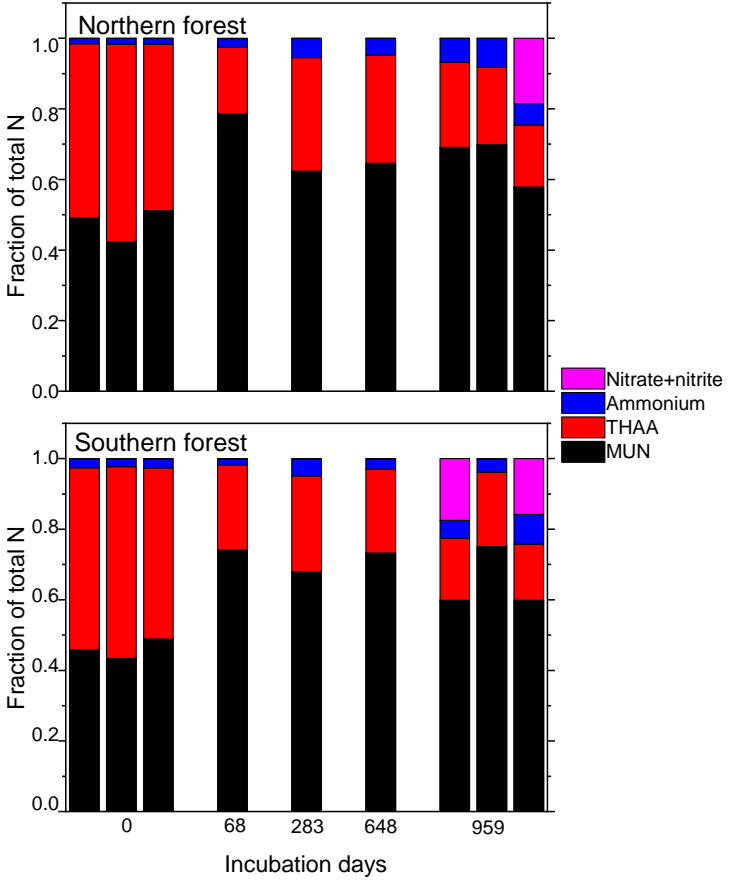

Figure 4. Fraction of the total moss tissue $\mathrm{N}$ content as nitrate, ammonium, total hydrolyzable amino acids (THAAs), and molecularly unidentified N (MUN) in each sample. Total hydrolyzable amino acids were only reported for one triplicate of the $18^{\circ} \mathrm{C}$ incubations for the middle time points $(69,283$, and 648 days $)$, though all samples were tested for the inorganic $\mathrm{N}$ species.

tially decomposed balsam fir litter in the northern forest and $\sim 83 \%$ in the southern forest, according to visual inspection. Despite their more advanced state of degradation compared to the fresh moss litter, the $L$ horizon soils also experienced $\mathrm{C}$ losses similar to those experienced by the moss samples $(30 \%-45 \%)$ in a shorter time period (68 weeks). The low decay rates observed are unlikely to be an artifact of the laboratory approach, as Bengtsson et al. (2016) compared fieldbased litter bag and laboratory incubation approaches using a common set of Sphagnum mosses and found that the laboratory approach generally resulted in greater mass loss.

The northern forest mosses, but not the southern forest mosses, exhibited higher $Q_{10}$ than the bulk $L$ horizon soil (Laganière et al., 2015; Podrebarac et al., 2016) and previous findings for vascular plant tissue decomposition (e.g., Fierer et al., 2005) based on the decay rate of the labile $C$ fraction. However, the higher temperature only slightly increased the total C degraded after 959 days. The $Q_{10}$ value based on total mass loss was therefore lower than the $L$ horizon soils. This indicates that the additional energy in the warmer treatment was not sufficient in inducing additional decomposition, suggesting that decomposition was not limited by activation energy, contrary to the C-quality temperature hypothesis (Bosatta and Ågren, 1999; Davidson and Janssens, 2006). Warming and drying trends in the boreal regions that inhibit 


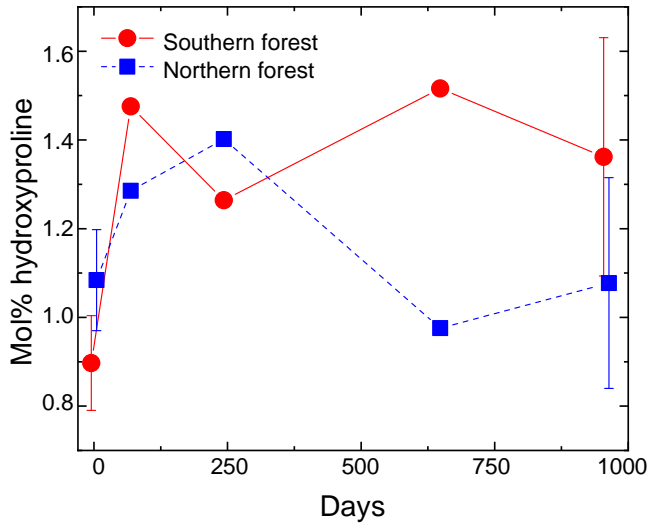

Figure 5. Hydroxyproline yields in the moss tissues as a percentage of total hydrolyzable amino acids. Error bars for the initial and final time points ( 0 and 959 days) indicate standard deviation $(n=3)$. The initial and final time points are jittered ( \pm 5 days) to display error bars without overplotting.

moss growth (Gower et al., 2001; Turetsky, 2003) could result in the formation of soil organic matter comprised of a greater relative abundance of vascular plant tissues, and thus of SOM that is both more decomposable and more temperature sensitive. This is consistent with our observations of increasing temperature sensitivity of soil respiration at lower latitudes along the boreal forest transect where moss inputs are reduced (Podrebarac et al., 2016).

We did not observe significant differences between sites' total C loss or $Q_{10}$, despite differences in the moss species incubated and their $\mathrm{C}: \mathrm{N}$. These results contrast with previous reports of the importance of species composition and $\mathrm{N}$ content in determining litter decay rates (Bengtsson et al., 2018; Bragazza et al., 2007; Hobbie, 1996; Lang et al., 2009; Limpens and Berendse, 2003). Decomposition studies utilizing a range of Sphagnum species have also found significant species effects (Bengtsson et al., 2018; Bragazza et al., 2007; Johnson and Damman, 1991; Turetsky et al., 2008). Our study utilized the mixture of moss species naturally occurring at each site, and we therefore cannot isolate the effect of species from that of regional differences in C:N. However, the lack of difference in moss decomposition temperature responses across regions, despite differences in the moss species represented, suggests that slow decomposition and low $Q_{10}$ are more widely distributed among upland mosses in these forest ecosystems.

\subsection{The cell-wall matrix governs low decomposition rates and temperature sensitivities of decay}

The low $Q_{10}$ values for total mass loss suggest that the low decay rates are not caused by chemical complexity or the recalcitrance of bulk moss tissues, properties associated with high activation energies and the correspondingly high temperature sensitivities of decay. This idea is supported by the

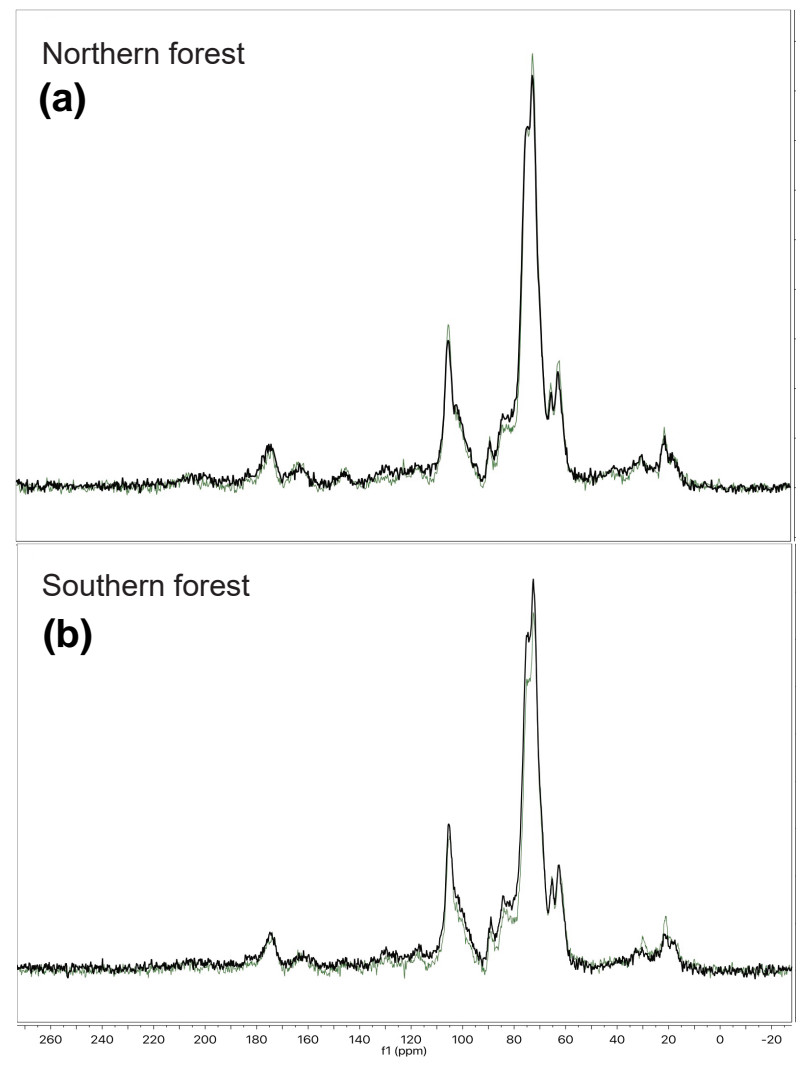

Figure 6. Examples of the CPMAS ${ }^{13} \mathrm{C}-\mathrm{NMR}$ results for 4 out of 12 samples analyzed. The four chosen here are from each of the two forest sites, with one undecomposed initial moss tissue replicate and the corresponding most decomposed replicate from the final time point of the $18^{\circ} \mathrm{C}$ incubation. Panel (a) provides examples from the northern forest site, and panel (b) provides examples from the southern forest site. The initial samples are in green, and a final sample from the $18^{\circ} \mathrm{C}$ incubation is in black. The $\mathrm{C}$ types and their ppm range are as follows: alkyl (50-0), O-alkyl (90-65), Di-O-alkyl (110-90), aromatic (165-110), and carbonyl and amide (190-165).

${ }^{13} \mathrm{C}$ NMR data, which indicate that the moss organic matter $(\mathrm{OM})$ is rich in carbohydrates, with little aromatic or alkyl C. The proportions of $\mathrm{O}$-alkyl $\mathrm{C}$ in mosses were higher than vascular plant litter collected from the same study sites $(55.3 \%$ vs. $37.0 \%$; Kohl et al., 2018). Further, the OM composition did not change significantly following incubation, unlike the decomposition of vascular plant tissues and SOM, in which O-alkyl C is often preferentially degraded and alkyl C increases in relative abundance (Baldock et al., 1997; KögelKnabner, 1997; Preston et al., 2009). The lack of change in the moss alkyl : O-alkyl ratio during decomposition does not appear to result from low mass loss in these incubations, given the increase in this ratio after a similar amount of mass loss (approximately $40 \%$ ) in the foliage of each of the 10 tree species in Canadian boreal forests (Preston et al., 2009). In conjunction with the relatively low temperature sensitivities of decay, the high proportion of O-alkyl C and lack of 

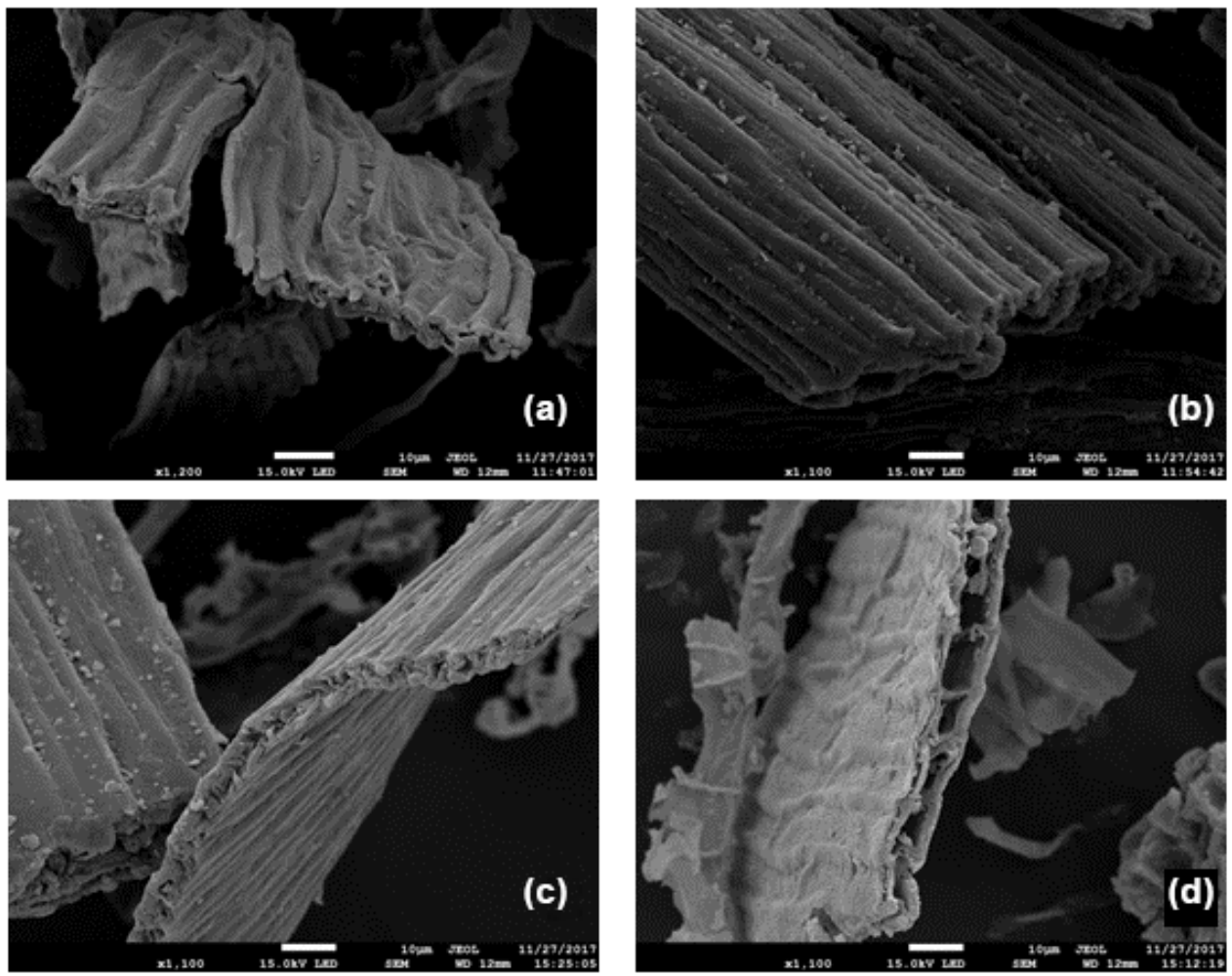

Figure 7. Representative scanning electron micrographs of moss tissues before (a, c) and after (b, d) incubation. Panels (a) and (b) depict mosses from the cooler forest, and the panels (c) and (d) depict mosses from the warmer forest.

change in the alkyl : O-alkyl ratio following decomposition suggests that something other than bulk chemical composition governs the relatively low decomposition rates observed during the moss incubations.

There is also no evidence that decay-inducing microorganisms were limited by $\mathrm{N}$ availability. Indeed, varying concentrations of moss tissue $\mathrm{N}$ and $\mathrm{C}: \mathrm{N}$ ratios across sites were not related to changing decay rates. Lower $\mathrm{C}: \mathrm{N}$ ratios are often correlated with faster decay in both mosses (Aerts et al., 2001; Bragazza et al., 2007; Limpens and Berendse, 2003) and vascular plant tissues (Nadelhoffer et al., 1991; Hobbie et al., 1996) in boreal soils, suggesting the $\mathrm{N}$ limitation of decomposition. However, in another field study $\mathrm{N}$ fertilization altered the $\mathrm{N}$ cycle but did not affect $\mathrm{C}$ losses from moss tissues (Manninen et al., 2016). The $\mathrm{N}$ content was significantly lower and $\mathrm{C}: \mathrm{N}$ was higher in the northern forest compared to the southern forest $(86.3 \pm 1.8$ and $53.0 \pm 3.1$, respectively), which would exacerbate $\mathrm{N}$ limitation in the northern forest moss tissues. The difference in $\mathrm{N}$ content appears to be related to site $\mathrm{N}$ availability rather than differences in moss species, because the $\mathrm{C}: \mathrm{N}$ of balsam fir needles are also higher in the northern forest than in the southern forest (Ziegler et al., 2017; Kohl et al., 2018). Limpens and Berendse (2003) demonstrated that Sphagnum decay resulted in net $\mathrm{N}$ mineralization below the threshold $\mathrm{C}: \mathrm{N}$ of
67. Our data are consistent with these results, as net $\mathrm{N}$ loss was observed for the southern forest moss with $\mathrm{C}: \mathrm{N}<67$ but not for the northern forest mosses with higher $\mathrm{C}: \mathrm{N}$, although species-specific differences between sites cannot be ruled out. Regardless of the causes for the higher $\mathrm{C}: \mathrm{N}$ in the northern forest mosses, the lack of difference in decomposition suggests that $\mathrm{N}$ availability was not the limiting factor for moss decay rates.

The changing composition of $\mathrm{N}$ during the incubations suggests that the rapid turnover of the $\mathrm{N}$ pool could have reduced microbial $\mathrm{N}$ limitation. The $\% \mathrm{~N}$ as THAAs declined from $\sim 50 \%$ to $\sim 20 \%$ in the first 69 days, while the amino acid degradation index declined from $\sim 2$ to $\sim-1$ over this period. Total $\mathrm{N}$ declined by $<15 \%$, and increases in inorganic $\mathrm{N}$ were $<5 \%$ over this period, indicating that the degraded organic $\mathrm{N}$ was mostly transformed into MUN. Previous studies indicate that the accumulation of amino sugars derived from microbial residues could contribute to the MUN pool (Tremblay and Benner, 2006). The decline in $\% \mathrm{~N}$ as THAAs and the degradation index are similar in magnitude to the difference in composition between the $L$ and the $H$ horizon in these soils (Philben et al., 2016). This indicates extensive degradation and the turnover of the relatively small moss $\mathrm{N}$ pool, perhaps explaining the apparent lack of microbial $\mathrm{N}$ limitation despite high $\mathrm{C}: \mathrm{N}$ ratios. The rapid turnover 


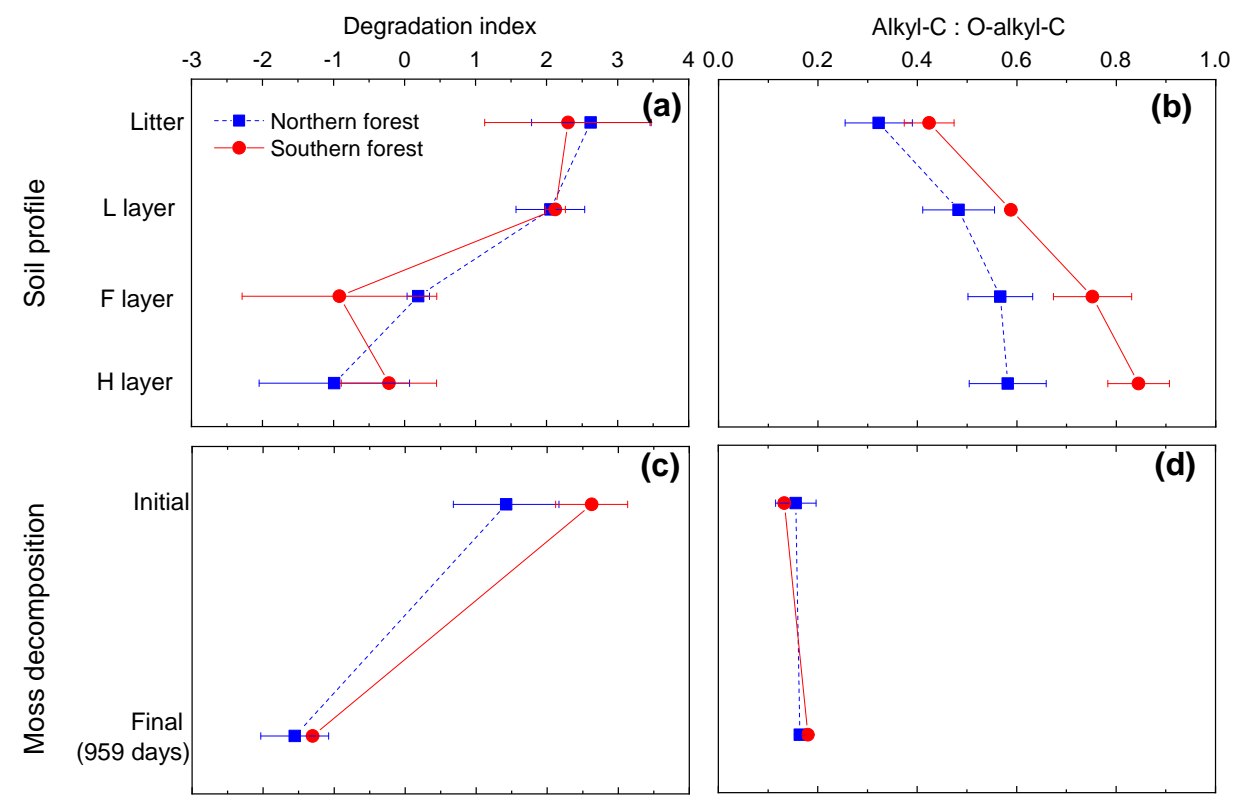

Figure 8. Panels (a) and (b) show the degradation index and alkyl-C : $\mathrm{O}-$ alkyl-C ratio for the soil profile in the cooler region (blue squares) and warmer region (red circles). Degradation index data from Philben et al. (2016). Panels (c) and (d) are calculated from this incubation data to contrast two methods for determining level of degradation for mosses. Data points are given as the mean, with standard deviation displayed as error bars.

of the $\mathrm{N}$ pool indicates the uncoupling of the $\mathrm{N}$ and $\mathrm{C}$ cycles in these incubations and suggests that the recalcitrant cellwall matrix does not protect most of the moss protein and peptide $\mathrm{N}$ pools, which appear to remain labile.

Despite the rapid turnover of the bulk amino acid pool, changing AA composition during the incubation indicates that the cell-wall matrix protected some proteins as well. Hyp is found in glycoproteins in the plant cell wall, but it lacks major microbial sources (Philben and Benner, 2013). The increase in Hyp relative to other amino acids in the incubations of the GC mosses therefore indicates the selective preservation of these cell-wall proteins. The northern forest incubations exhibit an increase in mol\% Hyp, followed by a decline to a value near to that of the pre-incubation sample. This regional difference is likely due to the difference in bulk $\mathrm{N}$ dynamics; the decline in $\mathrm{C}: \mathrm{N}$ during the northern forest incubations indicates microbial $\mathrm{N}$ immobilization, which would produce amino acids, but not Hyp, and would lower its mol\%. The dilution of Hyp by microbial protein synthesis appears to have counteracted the selective preservation of cell-wall glycoproteins in the northern forest. These dynamics further support the importance of the cell-wall matrix in organic matter stabilization during the incubations.

The persistence of the physical structure of the cell wall likely explains the observed combination of slow decomposition and its low temperature sensitivity. The SEM images indicate that microbial access to chemically labile $\mathrm{C}$ is inhibited by the biochemistry and the physical matrix of the cell wall of the moss. The lack of microbial access to otherwise reactive microbial resources appears to be a bottleneck to decomposition that is not alleviated by increasing temperature, explaining our observation of low $Q_{10}$ and a large O-alkyl C pool despite apparently recalcitrant litter.

Although they share a backbone of cellulose microfibrils, there are important chemical and structural differences between moss and vascular plant cell walls that could contribute to the persistence of the cell wall of the moss during the incubation (Roberts et al., 2012). Uronic acids (glucuronic acid and galacturonic acid) are more abundant in mosses than in vascular plants (Popper and Fry, 2003). The NMR spectra indicated that $\mathrm{O}$ - and di-O-alkyl functional groups account for $\sim 70 \%$ of the moss $\mathrm{C}$, but the molecular analysis of Sphagnum found about half of that total in five aldoses (glucose, galactose, mannose, rhamnose, and fucose; Philben et al., 2014), leaving a large pool of molecularly unidentified moss carbohydrates. The low ratio of Oalkyl to di-O-alkyl C (3.7 vs. $>4$ in vascular plants) suggests that uronic acids contribute to this pool. Sphagnum also produces a group of pectin-like carbohydrates (termed "sphagnan") composed primarily of rhamnose, mannose, and galacturonic acid (Ballance et al., 2007). This mixture appears to be resistant to decomposition and/or possess antimicrobial properties (Hájek et al., 2011; Stalheim et al., 2009). While this fraction has only been identified in Sphagnum, uronic acid-enriched carbohydrates in these upland mosses could play a similar role.

The NMR spectra also indicate a substantial contribution of phenolic and aromatic C ( $7 \%$ of the total C), despite the 
lack of lignin. The relative abundance of this fraction increased during decomposition, indicating selective preservation. Tsuneda et al. (2001) identified an amorphous phenolic coating on the outside of the moss cell wall and proposed that a specialized fungal consortium is required to break it down. This is analogous to the accelerated degradation of lignin in wood by white rot fungi (Rice et al., 2006) and is a plausible explanation of the lack of cell-wall degradation observed in the SEM images as well as the accumulation of phenolic and aromatic $\mathrm{C}$. If key fungal species were excluded from the soil slurry used as a microbial inoculum in the incubations, or if incubation conditions were not favorable for their growth, then their absence could lead to the persistence of the cell wall's structural integrity.

Overall, our data suggest that some combination of the inherent molecular resistance to decomposition and the molecular architecture of the cell-wall matrix makes it difficult for microbes or their exoenzymes to access. While these analyses can identify biochemical differences between moss and vascular plant cell walls, we cannot identify which of these differences specifically contribute to their apparent recalcitrance. This presents an intriguing avenue for future research, as the persistence of the physiochemical integrity of the moss cell-wall matrix is likely important for maintaining the globally significant pools of moss-derived $\mathrm{C}$ in both peatlands and forested uplands.

\subsection{Implications for the bioavailability of boreal forest SOM}

The contrasting responses of the bulk $\mathrm{C}$ composition and the THAA-based indices during moss decomposition could complicate the interpretation of decay-focused data sets in moss-rich boreal forest soils. The decomposition of vascular plant tissues is typically characterized by the selective loss of carbohydrates. Indices such as the carbohydrate yield and the O-alkyl-to-alkyl ratio of ${ }^{13} \mathrm{C}$ NMR spectra have therefore become useful and widely used indicators of the degree of SOM degradation, albeit with some caution (Baldock et al., 1997). However, our results indicate that the O-alkyl C of moss tissues is not selectively degraded, and O-alkyl : alkyl $\mathrm{C}$ did not change following incubation (Fig. 8). The contribution of relatively recalcitrant moss-derived structural carbohydrates could cause the O-alkyl : alkyl C ratio to underestimate diagenesis in moss-rich boreal forest soils (Fig. 8d). In contrast, the change in the THAA-based indices $(\% \mathrm{~N}$ as THAAs and the degradation index) following incubation was similar to the change in depth in the organic horizon of these soils (Fig. 8a, c) and the change in the $L$ horizon during incubation (Philben et al., 2016). These results demonstrate that variations in biochemical composition among plant types can confound the conventional geochemical interpretation of diagenetic indices and underscore the value of using multiple independent indices for a holistic understanding of the degradation of different SOM components (Baldock et al., 1997).
Our measurements of the decay rates and $Q_{10}$ of mosses contrast with the latitudinal trends of bulk SOM bioavailability observed along the NL-BELT. Despite having the highest contribution of mosses to the organic horizon, incubation experiments indicated that the northern forest had the highest soil respiration rate (relative to initial soil C) and similar or lower $Q_{10}$ compared to the other regions (Laganière et al., 2015; Podrebarac et al., 2016). The slow decomposition of moss tissues therefore does not appear to result in the slower decomposition in of more moss-rich organic soils. However, the trend in organic matter composition is consistent with moss influence, as the coolest region is more enriched in $\mathrm{O}$ alkyl $\mathrm{C}$ and depleted in methoxy and aromatic $\mathrm{C}$ compared to the other regions (Kohl et al., 2018). The larger proportion of labile $\mathrm{C}$ compounds in the cooler region soils is correlated with the bioreactivity of the bulk soil during incubation (Kohl et al., 2018), suggesting that moss contributions of labile $\mathrm{C}$ override the effects of the slow decomposition of moss tissues themselves. This implies that the physical protection afforded by the cell wall declined in importance over time within the soil profile. It is possible that a fungal species or consortium absent from the soil inoculum is able to degrade the cell-wall phenolics in situ, enabling the broader microbial community to utilize the labile moss C. Physical processes associated with the burial of moss litter and incorporation into SOM could also contribute to a loss of cell-wall integrity over time. This study points to the need to better understand the physical and biochemical mechanisms controlling moss tissue decay and its variations among upland forest species and microhabitats, as these factors and their interaction impose important controls on boreal forest soil $\mathrm{C}$ stocks and their response to changing climate.

Data availability. All data are included in the paper tables and the Supplement.

Supplement. The supplement related to this article is available online at: https://doi.org/10.5194/bg-15-6731-2018-supplement.

Author contributions. SEZ, SAB, RB, and KAE designed the research with further input from MP. SB and MP analyzed data with NMR and SEM contributions from SEZ. MP and SB prepared the paper, with editing from SEZ and further contributions on final drafts from $\mathrm{RB}$ and $\mathrm{SAB}$.

Competing interests. The authors declare that they have no conflict of interest.

Acknowledgements. Comments from two anonymous reviewers helped to clarify and improve the paper. We thank Jamie Warren for overseeing the maintenance of the moss incubations and for 
assisting with sample processing and analysis. Julia Ferguson assisted with moss sample preparation and mesocosm setup and monitoring. Alex Morgan also assisted with incubation monitoring. We also thank Celine Schneider for conducting the ${ }^{13} \mathrm{C}$ NMR analyses, Alison Pye for conducting the stable isotope analyses, Wanda Aylward for conducting the SEM imaging, and Geert Van Biesen for assisting with the hydrolyzable amino acid analyses. This research was funded by the National Science and Engineering Councils of Canada Discovery Grants program and Strategic Project Grants program (STP-397494-10 and STPGP-479224), the Centre for Forest Science and Innovation of the Newfoundland and Labrador Forestry and Agrifoods Agency, the Canada Research Chairs Programme, and the Canadian Forest Service of Natural Resources Canada.

Edited by: Frank Hagedorn

Reviewed by: two anonymous referees

\section{References}

Aerts, R., Wallen, B., Malmer, N., and De Caluwe, H.: Nutritional constraints on Sphagnum-growth and potential decay in northern peatlands, J. Ecol., 89, 292-299, https://doi.org/10.1046/j.13652745.2001.00539.x, 2001.

Baldock, J. A., Oades, J. M., Nelson, P. N., Skene, T. M., Golchin, A., and Clarke, P.: Assessing the extent of decomposition of natural organic materials using solid-state ${ }^{13}$ C NMR spectroscopy, Aust. J. Soil Res., 35, 1061-1084, https://doi.org/10.1071/S97004, 1997.

Ballance, S., Børsheim, K. Y., Inngjerdingen, K., Paulsen, B. S., and Christensen, B. E.: A re-examination and partial characterisation of polysaccharides released by mild acid hydrolysis from the chlorite-treated leaves of Sphagnum papillosum, Carbohyd. Polym., 67, 104-115, https://doi.org/10.1016/J.CARBPOL.2006.04.020, 2007.

Bengtsson, F., Granath, G., and Rydin, H.: Photosynthesis, growth, and decay traits in Sphagnum - a multispecies comparison, Ecol. Evol., 6, 3325-3341, https://doi.org/10.1002/ece3.2119, 2016.

Bengtsson, F., Rydin, H., and Hájek, T.: Biochemical determinants of litter quality in 15 species of Sphagnum, Plant Soil, 425, 161176, https://doi.org/10.1007/s11104-018-3579-8, 2018.

Bona, K. A., Fyles, J. W., Shaw, C., and Kurz, W. A.: Are mosses required to accurately predict upland black spruce forest soil carbon in national-scale forest $\mathrm{C}$ accounting models?, Ecosystems, 16, 1071-1086, https://doi.org/10.1007/s10021-013-9668$\mathrm{x}, 2013$.

Bosatta, E. and Ågren, G. I.: Soil organic matter quality interpreted thermodynamically, Soil Biol. Biochem., 31, 1889-1891, https://doi.org/10.1016/S0038-0717(99)00105-4, 1999.

Bragazza, L., Siffi, C., Iacumin, P., and Gerdol, R.: Mass loss and nutrient release during litter decay in peatland: The role of microbial adaptability to litter chemistry, Soil Biol. Biochem., 39, 257267, https://doi.org/10.1016/J.SOILBIO.2006.07.014, 2007.

Coûteaux, M. M., Aloui, A., and Kurz-Besson, C.: Pinus halepensis litter decomposition in laboratory microcosms as influenced by temperature and a millipede, Glomeris marginata, Appl. Soil Ecol., 20, 85-96, https://doi.org/10.1016/S0929-1393(02)000136, 2002.
Dauwe, B. and Middelburg, J. J.: Amino acids and hexosamines as indicators of organic matter degradation state in North Sea sediments, Limnol. Oceanogr., 43, 782-798, https://doi.org/10.4319/lo.1998.43.5.0782, 1998.

Dauwe, B., Middelburg, J. J., Herman, P. M. J., and Heip, C. H. R.: Linking diagenetic alteration of amino acids and bulk organic matter reactivity, Limnol. Oceanogr., 44, 1809-1814, https://doi.org/10.4319/lo.1999.44.7.1809, 1999.

Davidson, E. A. and Janssens, I. A.: Temperature sensitivity of soil carbon decomposition and feedbacks to climate change, Nature, 440, 165-173, https://doi.org/10.1038/nature04514, 2006.

Fierer, N., Craine, J. M., McLauchlan, K., and Schimel, J. P.: Litter quality and the temperature sensitivity of decomposition, Ecology, 86, 320-326, https://doi.org/10.1890/04-1254, 2005.

Frolking, S., Goulden, M. L., Wofsy, S. C., Fan, S. M., Sutton, D. J., Munger, J. W., Bazzaz, A. M., Daube, B. C., Crill, P. M., Aber, J. D., Band, L. E., Wang, X., Savage, K., Moore, T., and Harriss, R. C.: Modelling temporal variability in the carbon balance of a spruce/moss boreal forest, Glob. Change Biol., 2, 343-366, https://doi.org/10.1111/j.1365-2486.1996.tb00086.x, 1996.

Fyles, J. W. and McGill, W. B.: Decomposition of boreal forest litters from central Alberta under laboratory conditions, Can. J. Forest Res., 17, 109-114, https://doi.org/10.1139/x87-021, 1987.

Gornall, J. L., Jónsdóttir, I. S., Woodin, S. J., and Van der Wal, R.: Arctic mosses govern below-ground environment and ecosystem processes, Oecologia, 153, 931-941, https://doi.org/10.1007/s00442-007-0785-0, 2007.

Gower, S. T., Krankina, O., and Olson, R. J.: Net primary production and carbon allocation patterns of boreal forest ecosystems, Ecol. Appl., 11, 1395-1411, https://doi.org/10.1890/10510761(2001)011[1395:NPPACA]2.0.CO;2, 2001.

Hagemann, U. and Moroni, M. T.: Moss and lichen decomposition in old-growth and harvested high-boreal forests estimated using the litterbag and minicontainer methods, Soil Biol. Biochem., 87, 10-24, https://doi.org/10.1016/j.soilbio.2015.04.002, 2015.

Hájek, T., Ballance, S., Limpens, J., Zijlstra, M., and Verhoeven, J. T. A.: Cell-wall polysaccharides play an important role in decay resistance of Sphagnum and actively depressed decomposition in vitro, Biogeochemistry, 103, 45-57, https://doi.org/10.1007/s10533-010-9444-3, 2011.

Harden, J. W., O'Neill, K. P., Trumbore, S. E., Veldhuis, H., and Stocks, B. J.: Moss and soil contributions to the annual net carbon flux of a maturing boreal forest, J. Geophys. Res.-Atmos, 102, 28805-28816, https://doi.org/10.1029/97JD02237, 1997.

Hobbie, S. E.: Temperature and Plant Species Control Over Litter Decomposition in Alaskan Tundra, Ecol. Monogr., 66, 503-522, https://doi.org/10.2307/2963492, 1996.

Hobbie, S. E., Schimel, J. P., Trumbore, S. E., and Randerson, J. R.: Controls over carbon storage and turnover in high-latitude soils, Glob. Change Biol., 6, 196-210, https://doi.org/10.1046/j.13652486.2000.06021.x, 2000.

Hogg, E. H.: Decay potential of hummock and hollow Sphagnum peats at different depths in a Swedish raised bog, Oikos, 66, 269278, https://doi.org/10.2307/3544814, 1993.

IPCC: Climate Change 2013: The Physical Science Basis. Contribution of Working Group I to the Fifth Assessment Report of the Intergovernmental Panel on Climate Change, edited by: Stocker, T. F., Qin, D., Plattner, G.-K., Tignor, M., Allen, S. K., Boschung, J., Nauels, A., Xia, Y., Bex, V., and Midgley, P. M., Cambridge 
University Press, Cambridge, UK and New York, NY, USA, 1535 pp., https://doi.org/10.1017/CBO9781107415324, 2013.

Johnson, L. C. and Damman, A. W.: Species-controlled Sphagnum decay on a south Swedish raised bog, Oikos, 61, 234-242, 1991.

Kane, E. S., Valentine, D. W., Schuur, E. A., and Dutta, K.: Soil carbon stabilization along climate and stand productivity gradients in black spruce forests of interior Alaska, Can. J. Forest Res., 35, 2118-2129, https://doi.org/10.1139/x05-093, 2005.

Kögel-Knabner, I.: ${ }^{13} \mathrm{C}$ and ${ }^{15} \mathrm{~N}$ NMR spectroscopy as a tool in soil organic matter studies, Geoderma, 80, 243-270, https://doi.org/10.1016/S0016-7061(97)00055-4, 1997.

Kohl, L., Philben, M., Edwards, K. A., Podrebarac, F. A., Warren, J., and Ziegler, S. E.: The origin of soil organic matter controls its composition and bioreactivity across a mesic boreal forest latitudinal gradient, Glob. Change Biol., 24, e458-e473, https://doi.org/10.1111/gcb.13887, 2018.

Laganière, J., Podrebarac, F., Billings, S. A., Edwards, K. A., and Ziegler, S. E.: A warmer climate reduces the bioreactivity of isolated boreal forest soil horizons without increasing the temperature sensitivity of respiratory $\mathrm{CO}_{2}$ loss, Soil Biol. Biochem., 84, 177-188, https://doi.org/10.1016/j.soilbio.2015.02.025, 2015.

Lang, S. I., Cornelissen, J. H., Klahn, T., Van Logtestijn, R. S., Broekman, R., Schweikert, W., and Aerts, R.: An experimental comparison of chemical traits and litter decomposition rates in a diverse range of subarctic bryophyte, lichen and vascular plant species, J. Ecol., 97, 886-900, https://doi.org/10.1111/j.13652745.2009.01538.x, 2009.

Limpens, J. and Berendse, F.: How litter quality affects mass loss and $\mathrm{N}$ loss from decomposing Sphagnum, Oikos, 103, 537-547, https://doi.org/10.1034/j.1600-0706.2003.12707.x, 2003.

Maksimova, V., Klavina, L., Bikovens, O., Zicmanis, A., and Purmalis, O.: Structural Characterization and Chemical Classification of Some Bryophytes Found in Latvia, Chem. Biodivers., 10, 1284-1294, https://doi.org/10.1002/cbdv.201300014, 2013.

Malhi, Y., Baldocchi, D. D., and Jarvis, P. G.: The carbon balance of tropical, temperate and boreal forests, Plant Cell Environ., 22, 715-740, https://doi.org/10.1046/j.1365-3040.1999.00453.x, 1999.

Manninen, S., Kivimäki, S., Leith, I. D., Leeson, S. R., and Sheppard, L. J.: Nitrogen deposition does not enhance Sphagnum decomposition, Sci. Total Environ., 571, 314-322, https://doi.org/10.1016/j.scitotenv.2016.07.152 2016.

Menzel, P., Anupama, K., Basavaiah, N., Das, B. K., Gaye, B., Herrmann, N., and Prasad, S.: The use of amino acid analyses in (palaeo-) limnological investigations: A comparative study of four Indian lakes in different climate regimes, Geochim. Cosmochim. Ac., 160, 25-37, https://doi.org/10.1016/j.gca.2015.03.028, 2015.

Moore, T. and Basiliko, N.: Decomposition in Boreal Peatlands, in: Boreal Peatland Ecosystems, Springer, Berlin Heidelberg, 125143, https://doi.org/10.1007/978-3-540-31913-9_7, 2006.

Nadelhoffer, K. J., Giblin, A. E., Shaver, G. R., and Laundre, J. A.: Effects of temperature and substrate quality on element mineralization in six arctic soils, Ecology, 72, 242-253, https://doi.org/10.2307/1938918, 1991.

Philben, M. and Benner, R.: Reactivity of hydroxyprolinerich glycoproteins and their potential as biochemical tracers of plant-derived nitrogen, Org. Geochem., 57, 11-22, https://doi.org/10.1016/j.orggeochem.2013.01.003, 2013.
Philben, M., Kaiser, K., and Benner, R.: Biochemical evidence for minimal vegetation change in peatlands of the West Siberian Lowland during the medieval climate anomaly and little ice age, J. Geophys. Res.-Biogeo., 119, 808-825, https://doi.org/10.1002/2013JG002396, 2014.

Philben, M., Ziegler, S. E., Edwards, K. A., Kahler, R., and Benner, R.: Soil organic nitrogen cycling increases with temperature and precipitation along a boreal forest latitudinal transect, Biogeochemistry, 127, 397-410, https://doi.org/10.1007/s10533016-0187-7, 2016.

Podrebarac, F. A., Laganière, J., Billings, S. A., Edwards, K. A., and Ziegler, S. E.: Soils isolated during incubation underestimate temperature sensitivity of respiration and its response to climate history, Soil Biol. Biochem., 93, 60-68, https://doi.org/10.1016/j.soilbio.2015.10.012, 2016.

Popper, Z. A. and Fry, S. C.: Primary cell wall composition of bryophytes and charophytes, Ann. Bot.-London, 91, 1-12, https://doi.org/10.1093/aob/mcg013, 2003.

Preston, C. M., Nault, J. R., and Trofymow, J. A.: Chemical Changes During 6 Years of Decomposition of 11 Litters in Some Canadian Forest Sites. Part 2. ${ }^{13} \mathrm{C}$ Abundance, Solid-State ${ }^{13}$ C NMR Spectroscopy and the Meaning of "Lignin", Ecosystems, 12, 1078-1102, https://doi.org/10.1007/s10021-009-9267z, 2009.

$\mathrm{R}$ Core Team: R: A language and environment for statistical computing, R Foundation for Statistical Computing, Vienna, Austria, available at: https://www.R-project.org/ (last access: 17 April 2018), 2016.

Rice, A. V., Tsuneda, A., and Currah, R. S.: In vitro decomposition of Sphagnum by some microfungi resembles white rot of wood, FEMS Microbiol. Ecol., 56, 372-382, https://doi.org/10.1111/j.1574-6941.2006.00071.x, 2006.

Roberts, A. W., Roberts, E. M., and Haigler, C. H.: Moss cell walls: structure and biosynthesis, Front. Plant Sci., 3, 166, https://doi.org/10.3389/fpls.2012.00166, 2012.

Stalheim, T., Ballance, S., Christensen, B. E., and Granum, P. E.: Sphagnan - a pectin-like polymer isolated from Sphagnum moss can inhibit the growth of some typical food spoilage and food poisoning bacteria by lowering the $\mathrm{pH}$, J. Appl. Microbiol., 106, 967-976, https://doi.org/10.1111/j.13652672.2008.04057.x, 2009.

Tremblay, L. and Benner, R.: Microbial contributions to $\mathrm{N}$ immobilization and organic matter preservation in decaying plant detritus, Geochim. Cosmochim. Ac., 70, 133-146, https://doi.org/10.1016/j.gca.2005.08.024, 2006.

Tsuneda, A., Thormann, M. N., and Currah, R. S.: Modes of cell-wall degradation of Sphagnum fuscum by Acremonium cf. curvulum and Oidiodendron maius, Can. J. Botany, 79, 93-100, https://doi.org/10.1139/b00-149, 2001.

Turetsky, M. R.: The Role of Bryophytes in Carbon and Nitrogen Cycling, Bryologist, 106, 395-409, https://doi.org/10.1639/05, 2003.

Turetsky, M. R., Crow, S. E., Evans, R. J., Vitt, D. H., and Wieder, R. K.: Trade-offs in resource allocation among moss species control decomposition in boreal peatlands, J. Ecol., 96, 1297-1305, https://doi.org/10.1111/j.1365-2745.2008.01438.x, 2008.

Turetsky, M. R., Mack, M. C., Hollingsworth, T. N., and Harden, J. W.: The role of mosses in ecosystem succession and function 
in Alaska's boreal forest, Can. J. Forest Res., 40, 1237-1264, https://doi.org/10.1139/X10-072, 2010.

Turetsky, M. R., Bond-Lamberty, B., Euskirchen, E., Talbot, J., Frolking, S., McGuire, A. D., and Tuittila, E. S.: The resilience and functional role of moss in boreal and arctic ecosystems, New Phytol., 196, 49-67, https://doi.org/10.1111/j.14698137.2012.04254.x, 2012.

Wetterstedt, J. T. M., Persson, T., and Ågren, G. I.: Temperature sensitivity and substrate quality in soil organic matter decomposition: Results of an incubation study with three substrates, Glob. Change Biol., 16, 1806-1819, https://doi.org/10.1111/j.13652486.2009.02112.x, 2010.
Ziegler, S. E., Benner, R., Billings, S. A., Edwards, K. A., Philben, M., Zhu, X., and Laganière, J.: Climate warming can accelerate carbon fluxes without changing soil carbon stocks, Front. Earth Sci., 5, 2, https://doi.org/10.3389/feart.2017.00002, 2017. 